Cochrane Database of Systematic Reviews

\title{
Surgery for scoliosis in Duchenne muscular dystrophy (Review)
}

Cheuk DKL, Wong V, Wraige E, Baxter P, Cole A

Cheuk DKL, Wong V, Wraige E, Baxter P, Cole A.

Surgery for scoliosis in Duchenne muscular dystrophy.

Cochrane Database of Systematic Reviews 2015, Issue 10. Art. No.: CD005375.

DOI: 10.1002/14651858.CD005375.pub4.

www.cochranelibrary.com 
TABLE OF CONTENTS

ABSTRACT

PLAIN LANGUAGE SUMMARY

BACKGROUND

OBJECTIVES

METHODS

RESULTS

Figure 1.

DISCUSSION

AUTHORS' CONCLUSIONS

ACKNOWLEDGEMENTS

REFERENCES

CHARACTERISTICS OF STUDIES

ADDITIONAL TABLES

APPENDICES

WHAT'S NEW

HISTORY

CONTRIBUTIONS OF AUTHORS

DECLARATIONS OF INTEREST

SOURCES OF SUPPORT

DIFFERENCES BETWEEN PROTOCOL AND REVIEW

NOTES

INDEX TERMS 
[Intervention Review]

\section{Surgery for scoliosis in Duchenne muscular dystrophy}

Daniel KL Cheuk ${ }^{1}$, Virginia Wong 2 , Elizabeth Wraige ${ }^{3}$, Peter Baxter ${ }^{4}$, Ashley Cole ${ }^{5}$

1Department of Pediatrics and Adolescent Medicine, The University of Hong Kong, Queen Mary Hospital, Hong Kong SAR, China.

2Department of Pediatrics and Adolescent Medicine, The University of Hong Kong, Queen Mary Hospital, Hong Kong, China.

3Department of Paediatric Neurology, Evelina Children's Hospital, St Thomas' Hospital, London, UK. ${ }^{4}$ Ryegate Children's Centre, Sheffield Children's Hospital, Sheffield, UK. 50rthopaedics Department, Sheffield Children's Hospital, Sheffield, UK

Contact: Daniel KL Cheuk, Department of Pediatrics and Adolescent Medicine, The University of Hong Kong, Queen Mary Hospital, Pokfulam Road, Hong Kong SAR, China. cheukkld@hkucc.hku.hk.

Editorial group: Cochrane Neuromuscular Group.

Publication status and date: New search for studies and content updated (no change to conclusions), published in Issue 10, 2015.

Citation: Cheuk DKL, Wong V, Wraige E, Baxter P, Cole A. Surgery for scoliosis in Duchenne muscular dystrophy. Cochrane Database of Systematic Reviews 2015, Issue 10. Art. No.: CD005375. DOI: 10.1002/14651858.CD005375.pub4.

Copyright ( 2015 The Cochrane Collaboration. Published by John Wiley \& Sons, Ltd.

\section{A B S T R A C T}

\section{Background}

Scoliosis in patients with Duchenne muscular dystrophy (DMD) is usually progressive and is treated with surgery. However, it is unclear whether the existing evidence is sufficiently scientifically rigorous to support a recommendation for spinal surgery for most patients with DMD and scoliosis. This is an updated review, and an updated search was undertaken in which no new studies were found for inclusion.

\section{Objectives}

To determine the effectiveness and safety of spinal surgery in patients with DMD with scoliosis. We intended to test whether spinal surgery is effective in increasing survival and improving respiratory function, quality of life, and overall functioning, and whether spinal surgery is associated with severe adverse effects.

\section{Search methods}

On 16 June 2015 we searched the Cochrane Neuromuscular Disease Group Specialized Register, the Cochrane Central Register of Controlled Trials (CENTRAL), MEDLINE, EMBASE, and CINAHL Plus. We also searched ProQuest Dissertation and Thesis database (January 1980 to June 2015), the National Institutes of Health Clinical Trials Database (6 January 2015), and the WHO International Clinical Trials Registry Platform (17 June 2015), and checked references. We imposed no language restrictions.

\section{Selection criteria}

We planned to include controlled clinical trials using random or quasi-random allocation of treatment evaluating all forms of spinal surgery for scoliosis in patients with DMD in the review. The control interventions would have been no treatment, non-operative treatment, or a different form of spinal surgery.

\section{Data collection and analysis}

We used standard methodological procedures expected by The Cochrane Collaboration. Two review authors independently examined the search results and evaluated the study characteristics against inclusion criteria in order to decide which studies to include in the review.

\section{Main results}

Of the 49 relevant studies we found, none met the inclusion criteria for the review because they were not clinical trials, but prospective or retrospective reviews of case series. 


\section{Authors' conclusions}

Since no randomized controlled clinical trials were available to evaluate the effectiveness of scoliosis surgery in patients with DMD, we can make no good evidence-based conclusion to guide clinical practice. Patients with scoliosis should be informed as to the uncertainty of benefits and potential risks of surgery for scoliosis. Randomized controlled trials are needed to investigate the effectiveness of scoliosis surgery, in terms of quality of life, functional status, respiratory function, and life expectancy.

\section{PLAIN LANGUAGE SUMMARY}

\section{Surgery for curvature of the spine in patients with Duchenne muscular dystrophy}

\section{Review question}

What is the effectiveness and safety of spinal surgery to treat scoliosis in patients with Duchenne muscular dystrophy (DMD)?

\section{Background}

Scoliosis, or curvature of the spine, is common in patients with DMD. It is usually progressive, and surgery is often performed to halt its progression, improve cosmetic appearance, facilitate care, preserve upper limb and respiratory function, and hopefully increase life expectancy. We wished to learn whether spinal surgery was better or worse than the alternatives.

\section{Study characteristics}

We found no randomized controlled trials.

\section{Key results and quality of the evidence}

We found 49 relevant studies, however they were not clinical trials but prospective or retrospective reviews of case series. The quality of evidence was very low because no clinical trial was available. This is an updated review, and an updated search was undertaken in which no new studies were found.

\section{Conclusion}

No randomized controlled clinical trials are available to evaluate the effectiveness of scoliosis surgery in patients with DMD. Randomized controlled clinical trials are needed in this group of patients to evaluate the benefits and risks of different surgical treatments.

The evidence is current to 5 January 2015. 


\section{B A C K G R O U N D}

\section{Description of the condition}

Duchenne muscular dystrophy (DMD) is an inherited X-linked muscular dystrophy caused by mutations in the dystrophin gene. It is characterized by progressive dystrophic changes in skeletal and cardiac muscle. Progressive weakness in affected children results in loss of ambulation at a mean age of 9.5 years (van Essen 1997). There is progressive cardiomyopathy, and respiratory failure occurs secondary to respiratory muscle weakness. The mean survival in the absence of ventilatory support is 19.5 years (van Essen 1997). In $90 \%$ of patients, death is the result of respiratory failure, and in $10 \%$ the result of cardiac involvement. There is currently no proven effective curative treatment for this debilitating disease. A systematic review found that glucocorticoid therapy improves muscle strength and function in the short term. However, adverse effects were common and long-term benefits are uncertain (Manzur 2008).

Spinal deformity, especially scoliosis, is progressive in the majority of patients with DMD (Galasko 1995; Miller 1985). From the onset of spinal deformity, progression can be extremely rapid and impair unsupported sitting ability and further compromise respiratory and cardiac function (Hsu 1983). Kurz observed a $4 \%$ decrease in vital capacity for every $10 \%$ progression of the spinal curve in patients with DMD (Kurz 1983). Galasko found that on average, vital capacity decreases by $8 \%$ per year in patients with scoliosis secondary to DMD (Galasko 1992).

\section{Description of the intervention}

Spinal fusion surgery with instrumentation remains the mainstay of treatment for patients with DMD with scoliosis. Commonly used techniques are either based on sublaminar segmental wiring, such as Luque instrumentation, or the modern variants based on segmental pedicle screw and hook fixation such as Isola, Texas Scottish Rite Hospital (TSRH), or Universal Spine System. Two stainless steel or titanium rods are contoured to the desired spinal shape, and the spine reduced onto the rods, either with the sublaminar wires or segmental screws and hooks. Pelvic fixation is rarely required in DMD scoliosis, and the Galveston technique of rod insertion into the ileum, or more modern screw fixation can be used in some circumstances. Postoperative bracing is not required with modern fixation techniques.

Long-term corticosteroid treatment may slow the progression of scoliosis in patients with DMD and may reduce the need for surgery (Dooley 2010), but adverse effects are frequent (Alman 2004). Non-operative treatment such as bracing might not prevent the progression of this kind of spinal deformity because of the progressive nature of the underlying muscle disease (Cambridge 1987; Colbert 1987). Therefore, non-operative treatment is usually considered only in exceptional cases when a person refuses surgery or when a person has a very advanced deformity with poor general health (Forst 1997; Heller 1997; McCarthy 1999).

\section{How the intervention might work}

The potential advantages of surgery described in the literature include increased comfort and sitting tolerance (Bridwell 1999; Cambridge 1987; Marchesi 1997; Matsumura 1997; Miller 1991; Miller 1992; Rice 1998; Rideau 1984; Shapiro 1992), cosmetic improvement (Bellen 1993; Bridwell 1999), no need for orthopedic braces (Bellen 1993; Colbert 1987; Miller 1985; Noble Jamieson 1986), easier nursing care by parents (Bellen 1993), and pain relief (Bellen 1993; Galasko 1977; Miller 1991).

Nevertheless, the effects of spinal surgery on respiratory function and life expectancy are still controversial. Some studies reported that spinal fusion had no effects on the natural deterioration of respiratory function of patients with DMD (Kinali 2006; Miller 1988; Miller 1992; Shapiro 1992), at short-term and five-year follow-up (Miller 1991). In contrast, several studies reported stabilization of vital capacity in patients surgically treated for two to eight years (Galasko 1992; Galasko 1995; Rideau 1984; Velasco 2007). Regarding life expectancy, Galasko observed a lower mortality in patients surgically treated (Galasko 1992; Galasko 1995). However, other studies reported that spinal surgery did not improve life expectancy (Chataigner 1998; Gayet 1999; Kennedy 1995; Kinali 2006; Miller 1988). Adverse effects and complications during and after surgery are not uncommon, including ventilator-associated pneumonia (iatrogenic, in the postoperative period), wound dehiscence, surgical wound infection, hemorrhage, loosening of fixation, pseudarthrosis, deteriorated respiratory function, and increased difficulty with hand-to-head motions.

\section{Why it is important to do this review}

A randomized trial has demonstrated that although tendon surgery in patients with DMD may correct deformities, it could also result in more rapid deterioration of function in some patients, and there were no beneficial effects on strength or function (Manzur 1992). With increasing use of non-invasive ventilation in DMD patients with respiratory insufficiency, which may prolong the life expectancy, it is unclear to what extent increased survival is related to non-invasive ventilation rather than to other interventions, including scoliosis surgery. It remains uncertain whether the existing evidence is sufficiently scientifically rigorous to recommend spinal surgery for most patients with DMD and scoliosis. In this systematic review, we evaluated the effectiveness of various forms of spinal surgery in prolonging life expectancy, retarding the natural deterioration of respiratory function, and improving quality of life in DMD patients. We wanted to evaluate whether the benefits of surgery outweigh the risks in general and determine which patient subgroups are most likely to benefit. The review has been updated, most recently in 2015.

\section{O B JECT IVES}

The objectives of this systematic review were to determine the effectiveness and safety of spinal surgery in DMD patients with scoliosis. We intended to address whether spinal surgery:

1. is effective in increasing survival;

2. can improve respiratory function in the short term and long term;

3. can improve quality of life and overall functioning;

4. is associated with severe adverse effects.

\section{METHODS}

\section{Criteria for considering studies for this review}

\section{Types of studies}

We planned to include controlled clinical trials using random or quasi-random allocation of treatment in the review. 


\section{Types of participants}

We would include patients with DMD (defined as progressive limb girdle weakness with at least one of: (1) dystrophic changes on muscle biopsy with reduced or absent dystrophin staining; (2) deletion, duplication, or point mutation of dystrophin gene) and all degrees of scoliosis documented by appropriate X-rays.

It is possible that use of this definition might have resulted in the inclusion of some individuals with an intermediate or severe Becker phenotype. However, the inclusion of only biopsy-proven dystrophin negative cases could potentially result in the loss of some important data.

\section{Types of interventions}

We planned to include trials evaluating all forms of spinal surgery for scoliosis. The control interventions were to be no treatment, non-operative treatment, or a different form of spinal surgery.

\section{Types of outcome measures}

\section{Primary outcomes}

1. Survival: to allow for studies using different follow-up periods, we planned to use hazard ratios from survival data regression analysis.

\section{Secondary outcomes}

1. Respiratory function, as measured by pulmonary function tests such as forced vital capacity (FVC): medium term (3 to 12 months) and long term (more than 12 months). The results from studies with differing follow-up lengths were to be weighted appropriately to allow for this.

2. Medium- and long-term disability as measured by validated scales such as the Barthel index or Functional Independent Measure.

3. Medium- and long-term quality of life as measured by validated scales such as the 36-Item Short-Form Health Status Survey (SF-36).

4. Rate of progression of scoliosis, as measured by change of Cobb angle per year.

5. Frequency of severe adverse effects and complications, such as death related to surgery, deep surgical wound infection, wound dehiscence, loosening of fixation, pneumonia, pseudarthrosis, and the need for revision surgery.

\section{Search methods for identification of studies}

We searched the Cochrane Neuromuscular Disease Group Specialized Register (16 June 2015), the Cochrane Central Register of Controlled Trials (CENTRAL; 2015, Issue 12 in the Cochrane Library), MEDLINE (January 1966 to 16 June 2015), EMBASE (January 1947 to June 2015), CINAHL Plus (January 1937 to June 2015), ProQuest Dissertation and Thesis database (January 1980 to June 2015).

We also searched the following clinical trial registries:

- National Institutes of Health (NIH) Clinical Trials Database (www.ClinicalTrials.gov, accessed on 17 June 2015)

- World Health Organization (WHO) International Clinical Trials Registry Platform (ICTRP) (www.who.int/ictrp/en/, accessed on 17 June 2015)

\section{Electronic searches}

The detailed search strategies are in the appendices: MEDLINE (Appendix 1), EMBASE (Appendix 2), CENTRAL (Appendix 3), CINAHL Plus (Appendix 4), ProQuest Dissertation and Thesis database (Appendix 5), and the clinical trial registry databases (Appendix 6).

We used no language restriction in the search and inclusion of studies. However, we excluded multiple publications reporting the same group of patients or its subsets.

\section{Searching other resources}

The review authors searched the reference lists of all relevant papers for further studies. The process of searching many different sources might have brought to light direct or indirect references to unpublished studies. We planned to seek to obtain copies of such unpublished material. In addition, we contacted colleagues and experts in the field to identify any unpublished or ongoing studies.

\section{Data collection and analysis}

\section{Selection of studies}

Two review authors (DC and VW) independently reviewed titles and abstracts of references retrieved from the searches and selected all potentially relevant studies. We obtained copies of these articles, and the same review authors independently checked them against the inclusion criteria of the review. The review authors were not blinded to the names of the trial authors, institutions, or journal of publication. We planned that the same review authors (DC and VW) would independently extract data from included trials and assess trial quality. We would have resolved any disagreements by consensus.

Additional methods not applicable because of the lack of included studies are shown in Appendix 7.

\section{RES U LTS}

\section{Description of studies}

In January 2015, we found a total of 181 studies on electronic search of the databases (Cochrane Neuromuscular Disease Group Specialized Register: one study, CENTRAL: one study, MEDLINE: 22 studies, EMBASE: 15 studies, CINAHL Plus: 15 studies, ProQuest Dissertation and Thesis database: 126 studies, NIH Clinical Trials Database: one study, and WHO International Clinical Trial Registry: no studies). We identified an additional 32 studies on searching the reference lists of relevant studies. After removing duplicates, we screened a total of 204 studies, 155 of which we excluded as they did not focus on DMD or scoliosis surgery, or were narrative reviews. We examined the remaining 49 studies in detail but none of these satisfied the inclusion criteria. All of these studies were prospective or retrospective case series and were not clinical trials. Most of these studies also did not have a control group for comparison. Where a study did have a control group, the controls were patients who refused surgery or who were assigned a different treatment modality by the treating surgeons without randomization or quasirandomization. We therefore excluded these studies from further analyses because of a significant propensity for confounding and bias. The flow of studies is shown in Figure 1. 
Figure 1. Study flow diagram.

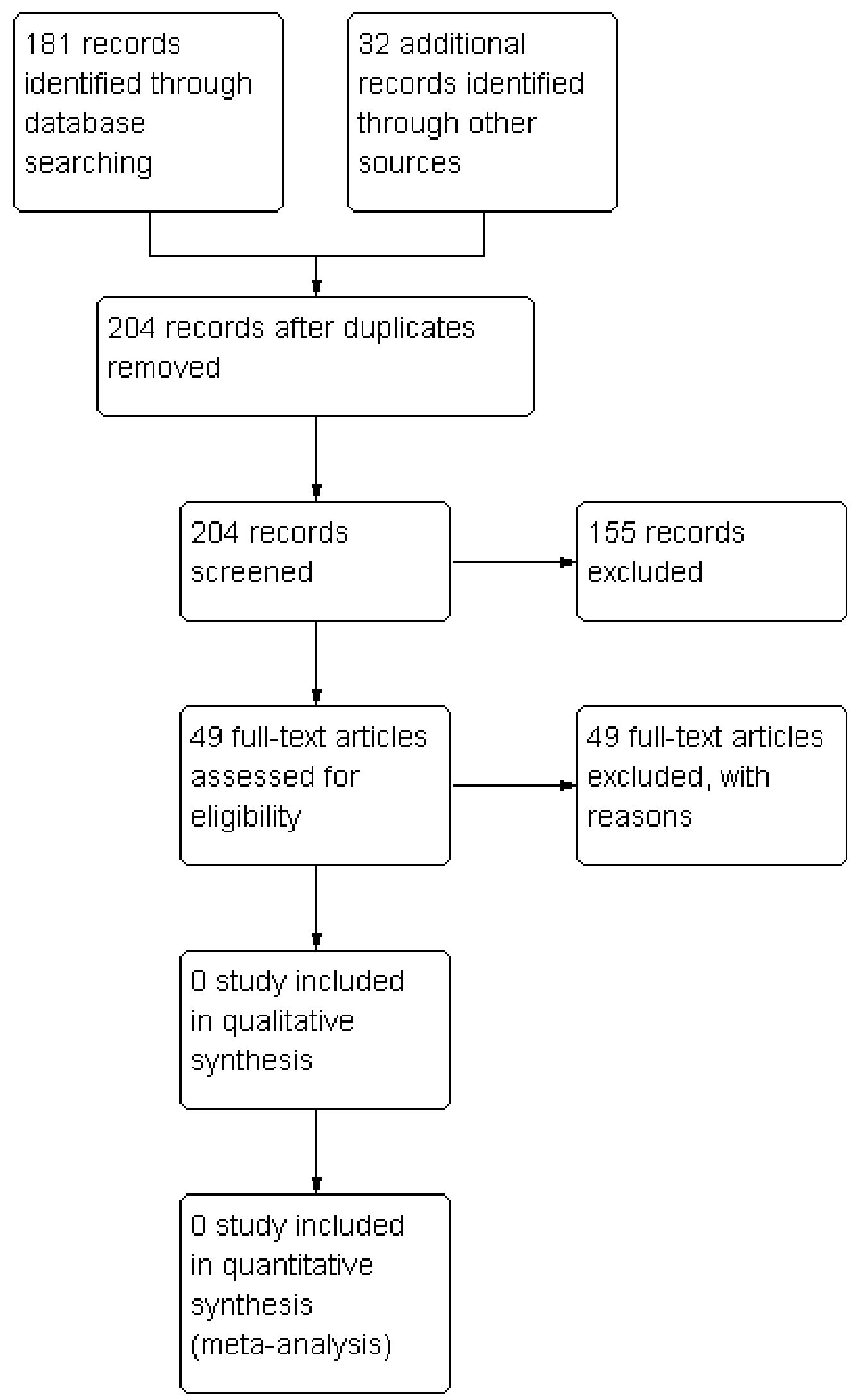




\section{Risk of bias in included studies}

Not applicable.

\section{Effects of interventions}

No controlled trials met the inclusion criteria of the review for further analyses.

\section{DISCUSSION}

Despite using a comprehensive search strategy for this review, we identified no randomized controlled trial of surgery for scoliosis in patients with DMD. Instead, we found many retrospective reviews or case series of patients with DMD and scoliosis treated with surgery. These studies showed varying results and had different conclusions. Although most agreed that surgery can improve patients' quality of life and functional status in terms of sitting posture, upper limb function, and ease of care, most failed to show a significant improvement in respiratory function or long-term survival, and short- and long-term postoperative complications were not uncommon.

However, a closer look at the relevant studies excluded may be helpful in guiding future clinical trials of scoliosis surgery for patients with DMD (Table 1). These 49 case series included 5 to 70 patients who had undergone scoliosis surgery. Eleven of these studies also included a comparison group of 21 to 115 patients without surgery (Alexander 2013; Eagle 2007; Galasko 1992; Galasko 1995; Kennedy 1995; Kinali 2006; Miller 1988; Miller 1991; Miller 1992; Sakai 1977; Suk 2014).

\section{Outcome measures and comparisons}

The studies had different objectives and focused on different outcomes. Most studies aimed to investigate whether spinal surgery improves the degree of scoliosis in the short term (immediate postoperative period) and in the long term (years later). Most studies used Cobb angle and degree of pelvic obliquity as outcome measures and described early and late complications of surgery. Some studies also reported degree of lumbar lordosis (Suk 2014), duration of hospitalization (Harper 2004; Rideau 1984; Sengupta 2002; Sussman 1984), perioperative mortality (Alman 1999; Bentley 2001; Brook 1996; Cambridge 1987; Cervellati 2004; Chataigner 1998; Dubousset 1983; Eagle 2007; Gaine 2004; Galasko 1992; Galasko 1995; Gayet 1999; Granata 1996; Hahn 2008; Harper 2004; Heller 2001; Hopf 1994; Kennedy 1995; LaPrade 1992; Marchesi 1997; Marsh 2003; Matsumura 1997; Modi 2009; Rideau 1984; Sakai 1977; Sengupta 2002; Shapiro 1992; Thacker 2002; Weimann 1983), and length of survival (Alexander 2013; Eagle 2007; Kinali 2006; Miller 1992). Many studies reported the change in respiratory function after operation (Alexander 2013; Brook 1996; Cervellati 2004; Chataigner 1998; Dubousset 1983; Eagle 2007; Galasko 1992; Galasko 1995; Gayet 1999; Granata 1996; Kennedy 1995; Kinali 2006; Matsumura 1997; Mehdian 1989; Miller 1988; Miller 1991; Miller 1992; Rideau 1984; Shapiro 1992; Suk 2014; Thacker 2002; Velasco 2007). The parameters used included vital capacity or forced vital capacity, peak expiratory flow rate, and forced expiratory volume in one second. A few studies also reported patient oriented subjective outcomes such as quality of life, functional status, self image, cosmetic appearance, pain, and patient satisfaction (Bentley 2001; Bridwell 1999; Granata 1996; Matsumura 1997; Miller 1991; Miller 1992; Rideau 1984; Suk 2014). While most studies evaluated the outcomes of spinal surgery in general, some studies attempted to compare different surgical techniques, such as Luque instrumentation versus Isola pedicle screw (Gaine 2004), sublaminar wiring versus intraspinous segmental wiring (LaPrade 1992), Luque instrumentation versus distal instrumentation with Galveston construct and rigid cross-linking (Brook 1996), Harrington-Luque instrumentation versus modified Luque instrumentation (Bentley 2001), Harrington instrumentation versus Luque instrumentation versus segmental spinal instrumentation with fusion (Sussman 1984), sublaminar instrumentation versus pedicle screw versus a hybrid system (Arun 2010), or autogenous versus allogenous bone graft (Nakazawa 2010). Some studies also compared the outcomes of spinal fusion to different extents (Alman 1999; Bridwell 1999; Gaine 2004; Mubarak 1993; Sengupta 2002; Modi 2010), such as fusion to $L 5$ versus fusion to sacrum. Some studies compared surgical outcomes in patients with different preoperative respiratory function (Harper 2004; Marsh 2003; Matsumura 1997; Sussman 1984).

\section{Outcomes on survival}

Most studies did not demonstrate obvious benefits of scoliosis surgery in terms of prolonging survival (Alexander 2013; Brook 1996; Cervellati 2004; Chataigner 1998; Gayet 1999; Granata 1996; Hahn 2008; Kennedy 1995; Kinali 2006; Mehdian 1989; Miller 1988; Miller 1991; Miller 1992; Shapiro 1992; Thacker 2002). One study showed that when spinal surgery was combined with nocturnal ventilation, patients had a longer median survival (30 years) compared with patients on nocturnal ventilation alone (22.2 years) (Eagle 2007). Another study showed that survival rate was higher at five years after surgery $(61 \%)$ compared to those who refused surgery (23\%) (Galasko 1995). In general, the age of death in patients with or without surgery was highly variable in the case series. Although most deaths could be attributed to respiratory infection, respiratory failure, progressive cardiomyopathy, and sudden cardiac death, in many cases the cause of death could not be ascertained. However, the age and causes of death did not seem to differ between patients with or without surgery. Perioperative mortality is generally uncommon. Most studies reported no perioperative mortality (Alman 1999; Bellen 1993; Bentley 2001; Bridwell 1999; Brook 1996; Cambridge 1987; Chataigner 1998; Dubousset 1983; Eagle 2007; Galasko 1992; Galasko 1995; Gayet 1999; Hopf 1994; Kennedy 1995; Kinali 2006; LaPrade 1992; Marchesi 1997; Marsh 2003; Matsumura 1997; Mehdian 1989; Miller 1992; Mubarak 1993; Nakazawa 2010; Rice 1998; Rideau 1984; Sakai 1977; Sengupta 2002; Stricker 1996; Sussman 1984; Takaso 2010; Thacker 2002; Weimann 1983), while some studies reported perioperative mortality ranging from $1.4 \%$ to 5\% (Modi 2009; Gaine 2004; Cervellati 2004; Granata 1996; Hahn 2008; Harper 2004; Heller 2001; Shapiro 1992).

\section{Outcomes on respiratory function}

Galasko found that forced vital capacity could be stabilized for three years and peak expiratory flow rate maintained for up to five years after spinal fusion (Galasko 1992; Galasko 1995). Rideau also found that vital capacity could be maintained static for two years (Rideau 1984), and three patients in Matsumura's study had increased forced vital capacity after operation (Matsumura 1997). Velasco found that the average rate of decline of forced vital capacity dropped from $4 \%$ per year to $1.75 \%$ per year after surgery (Velasco 2007). Suk found that deterioration in forced vital capacity was better in patients who had received spinal surgery 
compared with those who had not, but there was no significant difference in end-tidal $\mathrm{CO}_{2}$ or use of non-invasive positive pressure ventilation (Suk 2014). On the other hand, most studies did not demonstrate obvious benefits of scoliosis surgery in terms of respiratory function (Alexander 2013; Brook 1996; Chataigner 1998; Cervellati 2004; Eagle 2007; Gayet 1999; Granata 1996; Hahn 2008; Kennedy 1995; Kinali 2006; Mehdian 1989; Miller 1988; Miller 1991; Miller 1992; Shapiro 1992; Thacker 2002). While some studies found that patients with poor preoperative respiratory function fared similarly to those with better respiratory function (Marsh 2003; Harper 2004), other studies suggested that the prognosis was worse in patients with poorer preoperative respiratory function (Matsumura 1997; Sussman 1984).

\section{Functional outcome and quality of life}

In general, previous descriptive studies suggested that surgical correction of scoliosis resulted in better sitting position, functional status, quality of life, and patient satisfaction (Bentley 2001; Bridwell 1999; Cambridge 1987; Granata 1996; Marchesi 1997; Matsumura 1997; Miller 1991; Miller 1992; Rice 1998; Rideau 1984; Sakai 1977; Shapiro 1992; Suk 2014).

\section{Complications of spinal surgery}

Severe complications after spinal surgery are not infrequent and occur in up to $68 \%$ of patients (Modi 2009). These include cardiac arrest (Bentley 2001), cardiac arrhythmia (Harper 2004), heart block (Galasko 1992), respiratory failure requiring tracheostomy (Chataigner 1998; Galasko 1992; Galasko 1995; Harper 2004; Heller 2001; Marsh 2003) or mechanical ventilation postoperatively (Bentley 2001; Brook 1996; Heller 2001; Modi 2009), massive bleeding (Heller 2001; Modi 2008a), pneumonia (Bentley 2001; Galasko 1992; Harper 2004; Heller 2001; Modi 2009; Rideau 1984), pleural effusion (Harper 2004; Modi 2009), hemothorax or pneumothorax (Bentley 2001; Heller 2001; Modi 2009), spinal cord injury (Modi 2009), colonic perforation (Bentley 2001), bladder dysfunction (Bentley 2001; Hopf 1994), urinary tract infection (Modi 2009), deep wound infection (Arun 2010; Modi 2008a; Modi 2009; Sengupta 2002), infection necessitating removal or revision of surgical implants (Eagle 2007; Heller 2001), failure of implants (Arun 2010; Bentley 2001; Gaine 2004; Stricker 1996), dislodgement or dislocation of implants (Heller 2001; LaPrade 1992; Matsumura 1997), loosening of implants (Arun 2010; Modi 2009; Sengupta 2002), mechanical problems requiring revision surgery (Bentley 2001; Gaine 2004; Gayet 1999; Granata 1996; Sengupta 2002), pseudarthrosis (Gaine 2004; Thacker 2002), bone fracture (Alman 1999), pressure sores (Granata 1996; Modi 2009; Modi 2010), dural leak (LaPrade 1992), and deep vein thrombosis (Heller 2001). Several studies reported that postoperative complications were more frequent in patients with greater severity of scoliosis (Bentley 2001; Sakai 1977; Sussman 1984).

\section{Comparisons of different operative methods}

In general, fusion to sacrum does not offer benefits over fusion to a more proximal level (Gaine 2004; Mubarak 1993; Rice 1998; Sengupta 2002), unless scoliosis is severe and pelvic obliquity is significant (Alman 1999; LaPrade 1992; Modi 2010). Although none of the surgical methods was uniformly better than others, Isola system, in Gaine 2004, or segmental spinal fusion, in Miller 1991 and Miller 1992, might achieve better correction of deformity, and intraspinous wiring might result in shorter operative time and less blood loss compared to sublaminar wiring (LaPrade 1992). Pedicle screw system might also result in shorter operative time and less blood loss compared to sublaminar instrumentation system (Arun 2010).

We performed no meta-analysis of these available data because the retrospective, non-randomized, uncontrolled studies were observational in nature and were prone to bias and confounding. Currently there is an absence of high-level evidence supporting the use of scoliosis surgery in patients with DMD. There is also a lack of evidence for or against a particular modality of surgical approach. Controlled clinical trials with random allocation into treatment and control groups are needed before firm conclusions on the benefits and risks of scoliosis surgery in a patient with DMD can be made.

In the absence of evidence, it is our view that clinicians may need to consider anecdotal evidence and their personal experience as well as expert opinions as guidance for their decision on the best care for an individual patient. Potential benefits to quality of life and functional status as well as risks of morbidity and mortality should be fully discussed with patients before surgery for scoliosis is embarked upon. Patients should also be informed about the uncertainty of benefits on long-term survival and respiratory function after scoliosis surgery.

\section{AUTHORS' CONCLUSIONS}

\section{Implications for practice}

Since no randomized controlled trials (RCTs) were available to evaluate the effectiveness of scoliosis surgery in patients with Duchenne muscular dystrophy, we can make no good evidencebased conclusion to inform clinical practice.

\section{Implications for research}

RCTs are needed to investigate the effectiveness of scoliosis surgery, in terms of patient satisfaction, quality of life, functional status, respiratory function (forced vital capacity, forced expiratory volume in one second, peak expiratory flow), and survival. It should be feasible to randomize patients into surgery versus non-surgical management. Although placebo control treatment might not be feasible, random allocation of patients into different treatment groups is essential to avoid selection bias and ensure baseline comparability of different groups. Although blinding of patients and clinicians is almost impossible, blinding of outcome assessors is important and probably feasible. Quality of life and functional status should be assessed by validated questionnaires and instruments. RCTs should also investigate the relative benefits and risks of different surgical treatment modalities and different extents of spinal fusion. Stratifications by potentially important prognostic factors such as age, baseline respiratory function, and severity of scoliosis should be considered.

\section{ACKN OWLEDGEMENTS}

We wish to thank Sarah Massey and the Illingworth Library at the Sheffield Children's Hospital for their help and support in locating and retrieving studies. We also thank Angela Gunn for updating search strategies and searching various electronic databases.

Editorial support from the Cochrane Neuromuscular Disease Group for an earlier update was funded by the TREAT NMD Network European Union Grant 036825. 
This project was supported by the National Institute for Health Research via Cochrane Infrastructure funding to the Cochrane Neuromuscular Disease Group. The views and opinions expressed therein are those of the authors and do not necessarily reflect those of the Systematic Reviews Programme, National Institute for Health Research, National Health Service, or the Department of Health. The Cochrane Neuromuscular Disease Group is also supported by the MRC Centre for Neuromuscular Disease. 


\section{R E F E R E N C E S}

\section{References to studies excluded from this review}

Alexander 2013 \{published data only\}

Alexander WM, Smith M, Freeman BJ, Sutherland LM, Kennedy JD, Cundy PJ. The effect of posterior spinal fusion on respiratory function in Duchenne muscular dystrophy. European Spine Journal 2013;22(2):411-6.

\section{Alman 1999 \{published data only\}}

Alman BA, Kim HK. Pelvic obliquity after fusion of the spine in Duchenne muscular dystrophy. Journal of Bone and Joint Surgery. British Volume 1999;81(5):821-4.

\section{Arun 2010 \{published data only\}}

Arun R, Srinivas S, Mehdian SMH. Scoliosis in Duchennes muscular dystrophy: A changing trend in surgical management: A historical outcome study comparing sublaminar, hybrid and pedical screw instrumentation systems. European Spine Journal 2010;19(3):376-83.

\section{Bellen 1993 \{published data only\}}

Bellen P, Hody JL, Clairbois J, Denis N, Soudon P. The surgical treatment of spinal deformities in Duchenne muscular dystrophy. Journal of Orthopaedic Surgery (Hong Kong) 1993; 7:48-57.

\section{Bentley 2001 \{published data only\}}

Bentley G, Haddad F, Bull TM, Seingry D. The treatment of scoliosis in muscular dystrophy using modified Luque and Harrington-Luque instrumentation. Journal of Bone and Joint Surgery - Series B 2001;83(1):22-8.

Bridwell 1999 \{published data only\}

Bridwell KH, Baldus C, Iffrig TM, Lenke LG, Blanke K. Process measures and patient/parent evaluation of surgical management of spinal deformities in patients with progressive flaccid neuromuscular scoliosis (Duchenne's muscular dystrophy and spinal muscular atrophy). Spine 1999;24(13):1300-9.

\section{Brook 1996 \{published data only\}}

Brook PD, Kennedy JD, Stern LM, Sutherland AD, Foster BK. Spinal fusion in Duchenne's muscular dystrophy. Journal of Pediatric Orthopaedics 1996;16(3):324-31.

\section{Cambridge 1987 \{published data only\}}

Cambridge W, Drennan JC. Scoliosis associated with Duchenne muscular dystrophy. Journal of Pediatric Orthopedics 1987;7(4):436-40.

\section{Cervellati 2004 \{published data only\}}

Cervellati S, Bettini N, Moscato M, Gusella A, Dema E, Maresi R. Surgical treatment of spinal deformities in Duchenne muscular dystrophy: a long term follow-up study. European Spine Journal 2004;13(5):441-8.

\section{Chataigner 1998 \{published data only\}}

Chataigner H, Grelet V, Onimus M. Surgery of the spine in Duchenne's muscular dystrophy. Revue de Chirurgie
Orthopedique et Reparatrice de l'Appareil Moteur 1998;84(3):224-30.

Dubousset 1983 \{published data only\}

Dubousset J, Queneau P. Role and indications for surgery in Duchenne de Boulogne muscular dystrophy with rapid development. Revue de Chirurgie Orthopedique et Reparatrice de l'Appareil Moteur 1983;69(3):207-20.

\section{Eagle 2007 \{published data only\}}

Eagle M, Bourke J, Bullock R, Gibson M, Mehta J, Giddings D, et al. Managing Duchenne muscular dystrophy--the additive effect of spinal surgery and home nocturnal ventilation in improving survival. Neuromuscular Disorders. 2007;17(6):470-5.

Gaine 2004 \{published data only\}

Gaine WJ, Lim J, Stephenson W, Galasko CS. Progression of scoliosis after spinal fusion in Duchenne's muscular dystrophy. Journal of Bone and Joint Surgery. British Volume 2004;86(4):550-5.

Galasko 1992 \{published data only\} Galasko CSB, Delaney C, Morris P. Spinal stabilisation in Duchenne muscular dystrophy. Journal of Bone and Joint Surgery. British Volume 1992;74(2):210-4.

Galasko 1995 \{published data only\}

Galasko CSB, Williamson JB, Dalaney CM. Lung function in Duchenne muscular dystrophy. European Spine Journal 1995;4:263-7.

Gayet 1999 \{published data only\}

Gayet LE. Surgical treatment of scoliosis due to Duchenne muscular dystrophy. Chirurgie 1999;124(4):423-31.

Granata 1996 \{published data only\}

Granata C, Merlini L, Cervellati S, Ballestrazzi A, Giannini S, Corbascio $\mathrm{M}$, et al. Long-term results of spine surgery in Duchenne muscular dystrophy. Neuromuscular Disorders 1996;6(1):61-8

Hahn 2008 \{published data only\}

Hahn F, Hauser D, Espinosa N, Blumenthal S, Min K. Scoliosis correction with pedicle screws in Duchenne muscular dystrophy. European Spine Journal 2008;17(2):255-61.

Harper 2004 \{published data only\} Harper CM, Ambler G, Edge G. The prognostic value of preoperative predicted forced vital capacity in corrective spinal surgery for Duchenne's muscular dystrophy. Anaesthesia 2004;59(12):1160-2.

Heller 2001 \{published data only\} Heller KD, Wirtz DC, Siebert CH, Forst R. Spinal stabilization in Duchenne muscular dystrophy: principles of treatment and record of 31 operative treated cases. Journal of Pediatric Orthopedics. Part B 2001;10(1):18-24. 
Hopf 1994 \{published data only\}

Hopf C, Forst R, Forst J, Eysel P, Reitter B. Multi-segmental fusion of scoliosis in Duchenne's muscular dystrophy. Zeitschrift für Orthopädie und Ihre Grenzgebiete 1994;132(5):377-82.

\section{Kennedy 1995 \{published data only\}}

Kennedy JD, Staples AJ, Brook PD, Parsons DW, Sutherland AD, Martin AJ, et al. Effect of spinal surgery on lung function in Duchenne muscular dystrophy. Thorax 1995;50(11):1173-8.

\section{Kinali 2006 \{published data only\}}

Kinali M, Messina S, Mercuri E, Lehovsky J, Edge G, Manzur AY, et al. Management of scoliosis in Duchenne muscular dystrophy: a large 10-year retrospective study. Developmental Medicine \& Child Neurology 2006;48(6):513-8.

\section{LaPrade 1992 \{published data only\}}

LaPrade RF, Rowe DE. The operative treatment of scoliosis in Duchenne muscular dystrophy. Orthopaedic Review 1992;21(1):39-45.

\section{Marchesi 1997 \{published data only\}}

Marchesi D, Arlet V, Stricker U, Aebi M. Modification of the original Luque technique in the treatment of Duchenne's neuromuscular scoliosis. Journal of Pediatric Orthopedics 1997;17(6):743-9.

\section{Marsh 2003 \{published data only\}}

Marsh A, Edge G, Lehovsky J. Spinal fusion in patients with Duchenne's muscular dystrophy and a low forced vital capacity. European Spine Journal 2003;12(5):507-12.

\section{Matsumura 1997 \{published data only\}}

Matsumura T, Kang J, Nozaki S, Takahashi MP. The effect of spinal fusion on respiratory function and quality of life in Duchenne muscular dystrophy. Rinsho Shinkeigaku 1997;37(2):87-92.

\section{Mehdian 1989 \{published data only\}}

Mehdian H, Shimizu N, Draycott V, Evans G, Eisenstein S. Spinal stabilisation for scoliosis in Duchenne muscular dystrophy. Experience with various sublaminar instrumentation systems. Neuro-orthopedics 1989;7(2):74-82.

\section{Miller 1988 \{published data only\}}

Miller F, Moseley CF, Koreska J, Levison H. Pulmonary function and scoliosis in Duchenne dystrophy. Journal of Pediatric Orthopedics 1988;8(2):133-7.

\section{Miller 1991 \{published data only\}}

Miller RG, Chalmers AC, Dao H, Filler-Katz A, Holman B, Bost F. The effect of spine fusion on respiratory function in Duchenne muscular dystrophy. Neurology 1991;41(1):38-40.

Miller 1992 \{published data only\}

Miller F, Moseley CF, Koreska J. Spinal fusion in Duchenne muscular dystrophy. Developmental Medicine and Child Neurology 1992;34(9):775-86.

\section{Modi 2008a \{published data only\}}

Modi HN, Suh SW, Song HR, Fernandez HM, Yang JH. Treatment of neuromuscular scoliosis with posterior-only pedicle screw fixation. Journal of Orthopedic Surgery 2008;3:23.

\section{Modi 2008b \{published data only\}}

Modi HN, Suh SW, Song HR, Lee SH, Yang JH. Correction of apical axial rotation with pedicular screws in neuromuscular scoliosis. Journal of Spinal Disorders \& Techniques 2008;21(8):606-13.

\section{Modi 2009 \{published data only\}}

Modi HN, Suh SW, Yang JH, Cho JW, Hong JY, Singh SU, et al. Surgical complications in neuromuscular scoliosis operated with posterior-only approach using pedicle screw fixation. Scoliosis 2009;4:11.

\section{Modi 2010 \{published data only\}}

Modi HN, Woo Suh S, Song HR, Hyuk Yang J, Jajodia N. Evaluation of pelvic fixation in neuromuscular scoliosis: a retrospective study in 55 patients. International Orthopedics 2010;34(1):89-96

Mubarak 1993 \{published data only\}

Mubarak SJ, Morin WD, Leach J. Spinal fusion in Duchenne muscular dystrophy--fixation and fusion to the sacropelvis. Journal of Pediatric Orthopedics 1993;13(6):752-7.

Nakazawa 2010 \{published data only\}

Nakazawa T, Takaso M, Imura T, Adachi K, Fukushima K, Saito W, et al. Autogenous iliac crest bone graft versus banked allograft bone in scoliosis surgery in patients with Duchenne muscular dystrophy. International Orthopaedics 2010;34(6):855-61.

Rice 1998 \{published data only\}

Rice JJ, Jeffers BL, Devitt AT, McManus F. Management of the collapsing spine for patients with Duchenne muscular dystrophy. Irish Journal of Medical Science 1998;167(4):242-5.

Rideau 1984 \{published data only\}

Rideau Y, Glorion B, Delaubier A, Tarle O, Bach J. The treatment of scoliosis in Duchenne muscular dystrophy. Muscle \& Nerve 1984;7(4):281-6.

\section{Sakai 1977 \{published data only\}}

Sakai DN, Hsu JD, Bonnett CA, Brown JC. Stabilization of the collapsing spine in Duchenne muscular dystrophy. Clinical Orthopaedics and Related Research 1977;128:256-60.

\section{Sengupta 2002 \{published data only\}}

Sengupta DK, Mehdian SH, McConnell JR, Eisenstein SM, Webb JK. Pelvic or lumbar fixation for the surgical management of scoliosis in Duchenne muscular dystrophy. Spine 2002;27(18):2072-9.

\section{Shapiro 1992 \{published data only\}}

Shapiro F, Sethna N, Colan S, Wohl ME, Specht L. Spinal fusion in Duchenne muscular dystrophy: a multidisciplinary approach. Muscle \& Nerve 1992;15(5):604-14. 
Stricker 1996 \{published data only\}

Stricker U, Moser H, Aebi M. Predominantly posterior instrumentation and fusion in neuromuscular and neurogenic scoliosis in children and adolescents. European Spine Journal 1996;5(2):101-6.

\section{Suk 2014 \{published data only\}}

Suk KS, Lee BH, Lee HM, Moon SH, Choi YC, Shin DE, et al. Functional outcomes in Duchenne muscular dystrophy scoliosis: comparison of the differences between surgical and nonsurgical treatment. Journal of Bone and Joint Surgery. American volume 2014;96(5):409-15.

\section{Sussman 1984 \{published data only\}}

Sussman MD. Advantage of early spinal stabilization and fusion in patients with Duchenne muscular dystrophy. Journal of Pediatric Orthopedics 1984;4(5):532-7.

\section{Takaso 2010 \{published data only\}}

Takaso M, Nakazawa T, Imura T, Okada T, Ueno M, Fukushima K, et al. Segmental pedicle screws instrumentation and fusion to $L 5$ for spinal deformity secondary to Duchenne muscular dystrophy: results with a minimum of 2 years followup. European Journal of Orthopaedic Surgery \& Traumatology 2010;20(6):453-61.

\section{Thacker 2002 \{published data only\}}

Thacker M, Hui JH, Wong HK, Chatterjee A, Lee EH. Spinal fusion and instrumentation for paediatric neuromuscular scoliosis: retrospective review. Journal of Orthopedic Surgery (Hong Kong) 2002;10(2):144-51.

\section{Velasco 2007 \{published data only\}}

Velasco MV, Colin AA, Zurakowski D, Darras BT, Shapiro F. Posterior spinal fusion for scoliosis in Duchenne muscular dystrophy diminishes the rate of respiratory decline. Spine 2007;32(4):459-65.

\section{Weimann 1983 \{published data only\}}

Weimann RL, Gibson DA, Moseley CF, Jones DC. Surgical stabilization of the spine in Duchenne muscular dystrophy. Spine 1983;8(7):776-80.

\section{Additional references}

\section{Alman 2004}

Alman BA, Raza SN, Biggar WD. Steroid treatment and the development of scoliosis in males with Duchenne muscular dystrophy. Journal of Bone and Joint Surgery (American Volume) 2004;86-A(3):519-24.

\section{Colbert 1987}

Colbert AP, Craig C. Scoliosis management in Duchenne muscular dystrophy: prospective study of modified Jewett hyperextension brace. Archives of Physical Medicine and Rehabilitation 1987;68(5 Pt 1):302-4.

\section{Dooley 2010}

Dooley JM, Gordon KE, MacSween JM. Impact of steroids on surgical experience of patients with Duchenne muscular dystrophy. Pediatric Neurology 2010;43(3):173-6.

\section{Egger 1997}

Egger M, Davey-Smith G, Schneider M, Minder C. Bias in meta-analysis detected by a simple, graphic test. $B M J$ 1997;315(7):629-34.

\section{Forst 1997}

Forst R, Forst J, Heller KD, Hengstler K. Characteristics in the treatment of scoliosis in muscular diseases. Zeitschrift fur Orthopadie und Ihre Grenzgebiete 1997;135(2):95-105.

\section{Galasko 1977}

Galasko CSB. Incidence of orthopaedic problems in children with muscle disease. Israel Journal of Medical Science 1977;13(2):165-76

\section{Heller 1997}

Heller KD, Forst R, Forst J, Hengstler K. Scoliosis in Duchenne muscular dystrophy: aspects of orthotic treatment. Prosthetics and Orthotics International 1997;21(3):202-9.

\section{Higgins 2002}

Higgins JP, Thompson SG. Quantifying heterogeneity in a metaanalysis. Statistics in Medicine 2002;21(11):1539-58.

\section{Higgins 2011}

Higgins JPT, Green S (editors). Cochrane Handbook for Systematic Reviews of Interventions Version 5.1.0 (updated March 2011). The Cochrane Collaboration, 2011. Available from www.cochrane-handbook.org.

\section{Hsu 1983}

Hsu JD. The natural history of spine curvature progression in the non-ambulatory Duchenne muscular patient. Spine 1983;8(7):771-5.

\section{Kurz 1983}

Kurz LT, Mubarak SJ, Schultz P, Park SM, Leach J. Correlation of scoliosis and pulmonary function in Duchenne muscular dystrophy. Journal of Pediatric Orthopedics 1983;3(3):347-53.

\section{Manzur 1992}

Manzur AY, Hyde SA, Rodillo E, Heckmatt JZ, Bentley G, Dubowitz V. A randomized controlled trial of early surgery in Duchenne muscular dystrophy. Neuromuscular Disorders 1992;2(5-6):379-87.

\section{Manzur 2008}

Manzur AY, Kuntzer T, Pike M, Swan A. Glucocorticoid corticosteroids for Duchenne muscular dystrophy. Cochrane Database of Systematic Reviews 2008, Issue 1. [DOI: 10.1002/14651858.CD003725]

\section{McCarthy 1999}

McCarthy RE. Management of neuromuscular scoliosis. Orthopedic Clinics of North America 1999;30(3):435-49. 


\section{Miller 1985}

Miller G, O'Connor J. Spinal bracing and respiratory function in Duchenne muscular dystrophy. Clinical Pediatrics 1985;24(2):94.

\section{Noble Jamieson 1986}

Noble Jamieson CM, Heckmatt JZ, Dubowitz V, Silverman M. Effects of posture and spinal bracing on respiratory function in neuromuscular disease. Archives of Disease in Childhood 1986;61(2):178-81.

\section{RevMan 2014 [Computer program]}

The Nordic Cochrane Centre, The Cochrane Collaboration. Review Manager (RevMan). Version 5.3. Copenhagen: The Nordic Cochrane Centre, The Cochrane Collaboration, 2014.

\section{van Essen 1997}

van Essen AJ, Verheij JBGM, Reefhuis J, Fidler V, Begeer JH, de Visser M, et al. The natural history of Duchenne muscular dystrophy. Analysis of data from Dutch survey and review of age related events (PhD thesis). 1997. Online Leyden Muscular Dystrophy pages. http://www.dmd.nl/vEssen_PhD3.pdf (accessed 13 July 2015). [ISBN 903670711 0]

\section{References to other published versions of this review Cheuk 2010}

Cheuk DKL, Wong V, Wraige E, Baxter P, Cole A, N'Diaye T, et al. Surgery for scoliosis in Duchenne muscular dystrophy. Cochrane Database of Systematic Reviews 2007, Issue 1. [DOI: 10.1002/14651858.CD005375.pub2]

\section{Cheuk 2013}

Cheuk DKL, Wong V, Wraige E, Baxter P, Cole A. Surgery for scoliosis in Duchenne muscular dystrophy. Cochrane Database of Systematic Reviews 2013, Issue 2. [DOI: 10.1002/14651858.CD005375.pub3]

\section{CHARACTERISTICS OF STUDIES}

Characteristics of excluded studies [ordered by study ID]

\begin{tabular}{|c|c|}
\hline Study & Reason for exclusion \\
\hline Alexander 2013 & Retrospective case series, not clinical trial \\
\hline Alman 1999 & Retrospective case series, not clinical trial \\
\hline Arun 2010 & Retrospective case series, not clinical trial \\
\hline Bellen 1993 & Retrospective case series, not clinical trial \\
\hline Bentley 2001 & Retrospective case series, not clinical trial \\
\hline Bridwell 1999 & Retrospective case series, not clinical trial \\
\hline Brook 1996 & Retrospective case series, not clinical trial \\
\hline Cambridge 1987 & Retrospective case series, not clinical trial \\
\hline Cervellati 2004 & Retrospective case series, not clinical trial \\
\hline Chataigner 1998 & Retrospective case series, not clinical trial \\
\hline Dubousset 1983 & Retrospective case series, not clinical trial \\
\hline Eagle 2007 & Retrospective case series, not clinical trial \\
\hline Gaine 2004 & Retrospective case series, not clinical trial \\
\hline Galasko 1992 & Retrospective case series, not clinical trial \\
\hline Galasko 1995 & Retrospective case series, not clinical trial \\
\hline Gayet 1999 & Retrospective case series, not clinical trial \\
\hline
\end{tabular}




\begin{tabular}{|c|c|}
\hline Study & Reason for exclusion \\
\hline Granata 1996 & Retrospective case series, not clinical trial \\
\hline Hahn 2008 & Retrospective case series, not clinical trial \\
\hline Harper 2004 & Prospective case series, not clinical trial. \\
\hline Heller 2001 & Prospective case series, not clinical trial. \\
\hline Hopf 1994 & Retrospective case series, not clinical trial \\
\hline Kennedy 1995 & Retrospective case series, not clinical trial \\
\hline Kinali 2006 & Retrospective case series, not clinical trial \\
\hline LaPrade 1992 & Retrospective case series, not clinical trial \\
\hline Marchesi 1997 & Retrospective case series, not clinical trial \\
\hline Marsh 2003 & Retrospective case series, not clinical trial \\
\hline Matsumura 1997 & Retrospective case series, not clinical trial \\
\hline Mehdian 1989 & Retrospective case series, not clinical trial \\
\hline Miller 1988 & Retrospective case series, not clinical trial \\
\hline Miller 1991 & Retrospective case series, not clinical trial \\
\hline Miller 1992 & Retrospective case series, not clinical trial \\
\hline Modi 2008a & Retrospective case series, not clinical trial \\
\hline Modi 2008b & Retrospective case series, not clinical trial \\
\hline Modi 2009 & Retrospective case series, not clinical trial \\
\hline Modi 2010 & Retrospective case series, not clinical trial \\
\hline Mubarak 1993 & Retrospective case series, not clinical trial \\
\hline Nakazawa 2010 & Prospective case series, not clinical trial \\
\hline Rice 1998 & Retrospective case series, not clinical trial \\
\hline Rideau 1984 & Retrospective case series, not clinical trial \\
\hline Sakai 1977 & Retrospective case series, not clinical trial \\
\hline Sengupta 2002 & Retrospective case series, not clinical trial \\
\hline Shapiro 1992 & Retrospective case series, not clinical trial \\
\hline Stricker 1996 & Retrospective case series, not clinical trial \\
\hline Suk 2014 & Prospective case series, not clinical trial \\
\hline
\end{tabular}




\begin{tabular}{ll}
\hline Study & Reason for exclusion \\
\hline Sussman 1984 & Retrospective case series, not clinical trial \\
\hline Takaso 2010 & Prospective case series, not clinical trial \\
\hline Thacker 2002 & Retrospective case series, not clinical trial \\
\hline Velasco 2007 & Retrospective case series, not clinical trial \\
\hline Weimann 1983 & Retrospective case series, not clinical trial \\
\hline
\end{tabular}

\section{ADDITIONAL TABLES}

Table 1. Characteristics of excluded studies

\begin{tabular}{|c|c|c|c|c|c|}
\hline $\begin{array}{l}\text { Study refer- } \\
\text { ence }\end{array}$ & $\begin{array}{l}\text { Number of } \\
\text { patients }\end{array}$ & Treatments & $\begin{array}{l}\text { Outcome } \\
\text { measures }\end{array}$ & Findings & Remarks \\
\hline $\begin{array}{l}\text { Alexander } \\
2013\end{array}$ & 65 & $\begin{array}{l}\text { Surgery (sub- } \\
\text { laminar wiring } \\
\text { with Luque- } \\
\text { Galveston or } \\
\text { supplemental } \\
\text { pedicle screw } \\
\text { fixation, or } \\
\text { both) (28), no } \\
\text { surgery (26) }\end{array}$ & $\begin{array}{l}\text { Cobb angle, } \\
\text { percentage of } \\
\text { predicted FVC } \\
\text { (\%FVC), mor- } \\
\text { tality }\end{array}$ & $\begin{array}{l}\text { Mean correction of Cobb angle was } 34.8^{\circ} \text { in } \\
\text { the surgical group and mean deterioration } \\
\text { was } 16.1^{\circ} \text { in the non-surgical group. There } \\
\text { was no significant difference in the rate of } \\
\text { decline in \%FVC per year between surgical } \\
\text { group ( } 5.6 \% \text { decline/year) and non-surgical } \\
\text { group ( } 6.9 \% \text { decline/year). There was no sig- } \\
\text { nificant difference in the mean age of death } \\
\text { between the } 2 \text { groups }\end{array}$ & \\
\hline Alman 1999 & 48 & $\begin{array}{l}\text { Spinal fusion } \\
\text { to L5 (38) or } \\
\text { spinal fusion } \\
\text { to sacrum (10) } \\
\text { using multi- } \\
\text { ple-level sub- } \\
\text { laminar wires } \\
\text { with either } \\
\text { a modified } \\
\text { unit rod with } \\
\text { Galveston ex- } \\
\text { tensions to } \\
\text { the pelvis cut- } \\
\text { off, a modi- } \\
\text { fied rod with } \\
\text { a cross-link } \\
\text { placed at the } \\
\text { caudal end, or } \\
2 \text { Luque rods }\end{array}$ & $\begin{array}{l}\text { Cobb angle, } \\
\text { torso decom- } \\
\text { pensation, sit- } \\
\text { ting obliquity, } \\
\text { spinal obliqui- } \\
\text { ty, need for re- } \\
\text { vision surgery, } \\
\text { mortality }\end{array}$ & $\begin{array}{l}\text { Sitting obliquity and spinal obliquity in- } \\
\text { creased in patients fused to L5. } 2 \text { patients } \\
\text { had fracture of L5 lamina. } 2 \text { patients re- } \\
\text { quired revision surgery }\end{array}$ & \\
\hline Arun 2010 & 43 & $\begin{array}{l}\text { Sublaminar } \\
\text { instrumenta- } \\
\text { tion (19) or } \\
\text { hybrid sub- } \\
\text { laminar and } \\
\text { pedicle screw } \\
\text { (13) or pedical } \\
\text { screw (11) }\end{array}$ & $\begin{array}{l}\text { Cobb angle, } \\
\text { flexibility in- } \\
\text { dex, blood } \\
\text { loss, operat- } \\
\text { ing time, com- } \\
\text { plications }\end{array}$ & $\begin{array}{l}\text { Percentage correction of Cobb angle was } \\
72.5+/-14.5 \% \text { (Group A), } 82+/-6 \% \text { (Group } \\
\text { B), and } 82+/-8 \% \text { (Group C). Flexibility in- } \\
\text { dices were } 60+/-6.33 \% \text { (Group A), } 70+/- \\
4.65 \% \text { (Group B), and } 67+/-6.79 \% \text { (Group } \\
\text { C). Mean blood loss was } 4.1 \text { L (Group A), } 3.2 \\
\text { L (Group B), and } 2.5 \text { L (Group C). Mean oper- } \\
\text { ating times were } 300 \text { min (Group A), } 274 \text { min }\end{array}$ & $\begin{array}{l}\text { Concluded } \\
\text { that pedicle } \\
\text { screw system } \\
\text { might be fa- } \\
\text { vored because } \\
\text { of the lesser } \\
\text { blood loss and } \\
\text { surgical time }\end{array}$ \\
\hline
\end{tabular}


Table 1. Characteristics of excluded studies (Continued)

(Group B), and 234 min (Group C). Complications: 3 wound infections and 2 implant failure (Group A), 1 implant failure (Group B), 1 wound infection and 1 partial screw pull-out (Group C)

\begin{tabular}{|c|c|c|c|c|c|}
\hline Bellen 1993 & 47 & $\begin{array}{l}\text { Segmental } \\
\text { spinal instru- } \\
\text { mentation } \\
\text { according to } \\
\text { Luque's tech- } \\
\text { nique }\end{array}$ & $\begin{array}{l}\text { Mortality, } \\
\text { complications }\end{array}$ & $\begin{array}{l}\text { Many patients had general and pulmonary } \\
\text { and mechanical complications }\end{array}$ & $\begin{array}{l}\text { Concluded } \\
\text { that a to- } \\
\text { tal spinal } \\
\text { arthrodesis } \\
\text { could proba- } \\
\text { bly be avoid- } \\
\text { ed in these pa- } \\
\text { tients, who of- } \\
\text { ten demon- } \\
\text { strate a satis- } \\
\text { fying sponta- } \\
\text { neous fusion } \\
\text { after instru- } \\
\text { mentation }\end{array}$ \\
\hline Bentley 2001 & $\begin{array}{l}101 \text { (includ- } \\
\text { ed } 33 \text { patients } \\
\text { with SMA and } \\
4 \text { patients } \\
\text { with congen- } \\
\text { ital muscular } \\
\text { dystrophy) }\end{array}$ & $\begin{array}{l}\text { Modified } \\
\text { Luque (87), } \\
\text { Harring- } \\
\text { ton-Luque } \\
\text { (14) }\end{array}$ & $\begin{array}{l}\text { Cobb angle, } \\
\text { pelvic obliq- } \\
\text { uity, mortali- } \\
\text { ty, complica- } \\
\text { tions, patient } \\
\text { satisfaction }\end{array}$ & $\begin{array}{l}\text { Cobb angle decreased from } 70^{\circ} \text { to } 37^{\circ} \text {, pelvic } \\
\text { obliquity decreased from } 20^{\circ} \text { to } 13^{\circ} \text {. Ear- } \\
\text { ly severe complications in } 10 \text { patients, late } \\
\text { complications in } 24 \text { patients. No periop- } \\
\text { erative mortality. Excellent satisfaction in } \\
89.6 \% \text { of patients }\end{array}$ & $\begin{array}{l}\text { Incidence of } \\
\text { minor or tem- } \\
\text { porary com- } \\
\text { plications was } \\
\text { high, but oc- } \\
\text { curred chiefly } \\
\text { in patients } \\
\text { with very se- } \\
\text { vere curves } \\
\text { and consider- } \\
\text { able pre-exist- } \\
\text { ing immobility }\end{array}$ \\
\hline
\end{tabular}

\begin{tabular}{|c|c|c|c|c|}
\hline Bridwell 1999 & $\begin{array}{l}33 \text { (included } \\
21 \text { patients } \\
\text { with SMA) }\end{array}$ & $\begin{array}{l}\text { Posterior seg- } \\
\text { mental spinal } \\
\text { instrumenta- } \\
\text { tion applied } \\
\text { from the up- } \\
\text { per thoracic } \\
\text { spine (T2, T3, } \\
\text { T4, T5) down } \\
\text { to L5 or the } \\
\text { sacrum and } \\
\text { pelvis. Ear- } \\
\text { ly in the se- } \\
\text { ries, patients } \\
\text { with DMD with } \\
\text { smaller curves } \\
\left(<40^{\circ} \text { ) were }\right. \\
\text { fixed to L5. } \\
\text { All had bilat- } \\
\text { eral segmen- } \\
\text { tal fixation } \\
\text { with Wiscon- } \\
\text { sin or sublam- } \\
\text { inar wires at } \\
\text { each level and } \\
\text { at times with } \\
\text { hook supple- }\end{array}$ & $\begin{array}{l}\text { Question- } \\
\text { naires to eval- } \\
\text { uate func- } \\
\text { tion, self im- } \\
\text { age, cosme- } \\
\text { sis, pain, pul- } \\
\text { monary sta- } \\
\text { tus, patient } \\
\text { care, quality } \\
\text { of life, satis- } \\
\text { faction, } \\
\text { radiographic } \\
\text { data }\end{array}$ & $\begin{array}{l}\text { All patients seemed to have benefited from } \\
\text { the surgery. Cosmesis, quality of life, and } \\
\text { overall satisfaction rated the highest }\end{array}$ \\
\hline
\end{tabular}


Table 1. Characteristics of excluded studies (Continued)

mentation.

All patients

fused to the

sacrum had

Galveston or

Galveston-like

fixation

\begin{tabular}{|c|c|c|c|c|c|}
\hline Brook 1996 & 17 & $\begin{array}{l}\text { L-rod instru- } \\
\text { mentation } \\
(10), \text { distal } \\
\text { instrumen- } \\
\text { tation with } \\
\text { Galveston } \\
\text { construct and } \\
\text { rigid cross- } \\
\text { linking (7) }\end{array}$ & $\begin{array}{l}\text { Cobb angle } \\
\text { and pelvic } \\
\text { obliquity, per- } \\
\text { centage of } \\
\text { predicted FVC } \\
\text { (\%FVC), mor- } \\
\text { tality, compli- } \\
\text { cations }\end{array}$ & $\begin{array}{l}\text { Correction of Cobb angle better in the } \\
\text { Galveston group ( } 63 \% \text { versus } 51 \%) \text {. No } \\
\text { pseudoarthroses or instrument failures in } \\
\text { the Galveston group. In total } 4 \text { patients had } \\
\text { FVC }<25 \%, 2 \text { required ventilation postoper- } \\
\text { atively. No other respiratory complications. } \\
\text { No perioperative mortality }\end{array}$ & $\begin{array}{l}\text { The effect of } \\
\text { surgery on } \\
\text { respiratory } \\
\text { function re- } \\
\text { mains uncer- } \\
\text { tain }\end{array}$ \\
\hline $\begin{array}{l}\text { Cambridge } \\
1987\end{array}$ & 14 & $\begin{array}{l}\text { Segmental } \\
\text { spinal instru- } \\
\text { mentation } \\
\text { (13), Harring- } \\
\text { ton distrac- } \\
\text { tion rods (1) }\end{array}$ & $\begin{array}{l}\text { Mortality, } \\
\text { complica- } \\
\text { tions, sitting } \\
\text { tolerance }\end{array}$ & $\begin{array}{l}\text { No perioperative mortality, } 1 \text { patient re- } \\
\text { quired repeated re-intubation. All patients } \\
\text { achieved excellent long-term sitting toler- } \\
\text { ance }\end{array}$ & $\begin{array}{l}\text { Recommend- } \\
\text { ed posterior } \\
\text { spinal fusion } \\
\text { with segmen- } \\
\text { tal instrumen- } \\
\text { tation when } \\
\text { scoliosis }> \\
30^{\circ} \text {. Spinal fu- } \\
\text { sion did not } \\
\text { increase life } \\
\text { expectancy } \\
\text { or pulmonary } \\
\text { function }\end{array}$ \\
\hline
\end{tabular}

\begin{tabular}{|c|c|c|c|c|}
\hline $\begin{array}{l}\text { Cervellati } \\
2004\end{array}$ & 20 & $\begin{array}{l}\text { Modified } \\
\text { Luque tech- } \\
\text { nique (19) } \\
\text { or Cotrel- } \\
\text { Dubousset in- } \\
\text { strumentation }\end{array}$ & $\begin{array}{l}\text { Cobb angle, } \\
\text { vital capacity, } \\
\text { mortality }\end{array}$ & $\begin{array}{l}\text { Mean correction of Cobb angle at follow-up } \\
\text { was } 28^{\circ} \text {. Mean loss of correction was } 6^{\circ} \text {. Vital } \\
\text { capacity showed a slow progression, slightly } \\
\text { inferior to its natural evolution in untreated } \\
\text { patients. Death in } 1 \text { patient }\end{array}$ \\
\hline
\end{tabular}

(1)

\begin{tabular}{|c|c|c|c|c|c|}
\hline $\begin{array}{l}\text { Chataigner } \\
1998\end{array}$ & 27 & $\begin{array}{l}\text { Sublaminar } \\
\text { wiring with } \\
\text { Luque rods } \\
\text { (5) or Hartshill } \\
\text { rectangle (22). } \\
\text { Sacral fix- } \\
\text { ation with } \\
\text { ilio-sacral } \\
\text { screws linked } \\
\text { to the rectan- } \\
\text { gle by Cotrel- } \\
\text { Dubousset } \\
\text { rods and } \\
\text { dominos (15) }\end{array}$ & $\begin{array}{l}\text { Cobb angle, } \\
\text { pelvic obliqui- } \\
\text { ty, coronal im- } \\
\text { balance, sagit- } \\
\text { tal imbalance, } \\
\text { vital capaci- } \\
\text { ty, mortality, } \\
\text { complications }\end{array}$ & $\begin{array}{l}\text { Scoliosis reduced to } 10^{\circ} \text { after surgery and } \\
13^{\circ} \text { after } 30 \text { months' follow-up. Pelvic obliq- } \\
\text { uity was reduced to } 4^{\circ} \text { after surgery and } 7^{\circ} \\
\text { after } 30 \text { months. A good spinal balance was } \\
\text { present in } 20 \text { patients after surgery. A coro- } \\
\text { nal or sagittal imbalance averaging } 40 \mathrm{~mm} \\
\text { was observed in } 22 \text { patients at follow-up. Vi- } \\
\text { tal capacity had annual decrease of } 6.4 \% \text {. } \\
17 \text { patients were alive with a } 50 \text { months' fol- } \\
\text { low-up. No operative mortality. } 1 \text { patient re- } \\
\text { quired tracheostomy postoperatively }\end{array}$ & $\begin{array}{l}\text { Concluded } \\
\text { that surgery } \\
\text { did not result } \\
\text { in respiratory } \\
\text { improvement } \\
\text { or in life dura- } \\
\text { tion lengthen- } \\
\text { ing }\end{array}$ \\
\hline $\begin{array}{l}\text { Dubousset } \\
1983\end{array}$ & 37 & $\begin{array}{l}\text { Luque rods, } \\
\text { Harrington } \\
\text { rods, segmen- }\end{array}$ & $\begin{array}{l}\text { Cobb angle, } \\
\text { vital capacity, } \\
\text { mortality }\end{array}$ & $\begin{array}{l}\text { Scoliosis reduced from } 80^{\circ} \text { to } 24^{\circ} \text {. No effect } \\
\text { on decline of vital capacity. No clear benefit } \\
\text { in length of survival }\end{array}$ & \\
\hline
\end{tabular}


Table 1. Characteristics of excluded studies (Continued)

tal instrumen-

tation

\begin{tabular}{|c|c|c|c|}
\hline Eagle 2007 & 75 & $\begin{array}{l}\text { Surgery and } \\
\text { nocturnal } \\
\text { ventilation } \\
\text { (27), noctur- } \\
\text { nal ventila- } \\
\text { tion only (13), } \\
\text { no surgery or } \\
\text { ventilation } \\
\text { (35) }\end{array}$ & $\begin{array}{l}\text { Survival, com- } \\
\text { plications, } \\
\text { FVC }\end{array}$ \\
\hline
\end{tabular}

No perioperative deaths. Complications: gastrointestinal bleeding (2), postoperative ileus (1), spinal infection requiring removal of surgical rods (1), pressure sores (1), chronic pain due to prominence of metal prosthesis (2). Mean FVC reduced significantly (mean $1.4 \mathrm{~L}$ to $1.13 \mathrm{~L}$ ) after 1 year. Median survival longer in surgery with ventilation group compared to ventilation alone (30 versus 22.2 years). Survival at 24 years higher in surgery with ventilation group compared to ventilation or no intervention ( $84 \%$ versus $34.6 \%$ versus $10.7 \%$ )

\begin{tabular}{lll}
\hline Gaine 2004 74 & Luque rod & Cobb angle, \\
& (55), Isola & pelvic obliqui- \\
& pedicle screw & ty, mortality, \\
& $(19)$ & complications
\end{tabular}

Fusion to S1 did not offer benefit over fusion to more proximal level.

Isola system appears to maintain a slightly better Cobb angle. 1 perioperative mortality due to cardiorespiratory failure. Complications: failure of implants (3), wound infection (2), pseudarthrosis (2), metal implant prominence requiring removal (1)

\begin{tabular}{llll}
\hline Galasko 199255 & $\begin{array}{l}\text { Surgery (32), } \\
\text { refused }\end{array}$ & Mortality, \\
& surgery (23) & complica- \\
& tions, FVC, PE- \\
& FR, Cobb an- \\
& gle
\end{tabular}

In surgery group, FVC static for 3 years then slightly decreased. Improved PEFR maintained for up to 5 years. Cobb angle improved from $47^{\circ}$ to $34^{\circ}$ at 5 years. Slightly improved survival with surgery. Complications: respiratory failure requiring tracheostomy (1), pneumonia (1), heart block (1), superficial wound infection (1)

\begin{tabular}{llll}
\hline Galasko 199576 & $\begin{array}{l}\text { Surgery } \\
\text { (48), refused }\end{array}$ & Mortality, \\
& surgery (28) & complica- \\
& & tions, FVC, PE- \\
& FR, Cobb an- \\
& gle
\end{tabular}

No pseudarthrosis or postoperative failures.
Annual decrease of FVC lower in surgery group (0.07 versus 0.15$)$. PEFR increased annually by $7.6 \mathrm{~L} / \mathrm{min}$ in surgery group but decreased annually by $7.6 \mathrm{~L} / \mathrm{min}$ in nonsurgery group. Cobb angle after 3 years better in surgery group $\left(34^{\circ}\right.$ versus $\left.93^{\circ}\right)$. At 5 years, survival higher in surgery group $(61 \%$ versus $23 \%)$. Complications: respiratory failure requiring tracheostomy (1)

\begin{tabular}{|c|c|c|c|c|c|}
\hline Gayet 1999 & 37 & $\begin{array}{l}\text { Pedicular } \\
\text { screwing sys- } \\
\text { tem in the } \\
\text { lumbo-sacral } \\
\text { area and } \\
\text { transversal } \\
\text { attachments } \\
\text { with steel } \\
\text { threads at the } \\
\text { thoracic level. } \\
\text { A sublaminar } \\
\text { fastening was } \\
\text { placed at L1 }\end{array}$ & $\begin{array}{l}\text { Vital capac- } \\
\text { ity, mortali- } \\
\text { ty, complica- } \\
\text { tions, Cobb } \\
\text { angle, pelvic } \\
\text { obliquity }\end{array}$ & $\begin{array}{l}\text { Cobb angle decreased from } 19^{\circ} \text { to } 5.2^{\circ} \text {, and } \\
9.5 \% \text { at the latest measurement. Pelvic bal- } \\
\text { ancing was corrected and results have held } \\
\text { over time. Vital capacity was reduced by } \\
3.6 \% \text { per year. Complications: stem rupture } \\
\text { (1), superficial infection (4) }\end{array}$ & $\begin{array}{l}\text { Cardiorespira- } \\
\text { tory function } \\
\text { and life ex- } \\
\text { pectancy were } \\
\text { not improved, } \\
\text { but most pa- } \\
\text { tients and } \\
\text { families were } \\
\text { very satisfied } \\
\text { by the com- } \\
\text { fort brought } \\
\text { about by the }\end{array}$ \\
\hline
\end{tabular}

Surgery for scoliosis in Duchenne muscular dystrophy (Review)
Spinal surgery did not improve FVC. Combined surgery and nocturnal ventilation improved survival surgery had better lung function and improved survival
Patients with 
Table 1. Characteristics of excluded studies (Continued)

\begin{tabular}{|c|c|c|c|}
\hline Granata 1996 & 30 & $\begin{array}{l}\text { Segmental } \\
\text { spinal instru- } \\
\text { mentation } \\
\text { and fusion }\end{array}$ & $\begin{array}{l}\text { Cobb angle, } \\
\text { mortality, } \\
\text { complica- } \\
\text { tions, vital ca- } \\
\text { pacity, qual- } \\
\text { ity of life, sit- } \\
\text { ting position, } \\
\text { esthetic im- } \\
\text { provement }\end{array}$ \\
\hline
\end{tabular}

29 patients had a mean $59 \%$ correction of scoliosis.

Very limited loss of correction over time. One died after cardiac arrest. Complications: pressure sore (1), metal prominence requiring trimming (1). Mean vital capacity decreased from $57+/-17 \%$ to $34+/-13 \%$ at $3.9+/-2$ years after surgery. The majority of the patients and their parents evaluated sitting position, esthetic improvement, and quality of life positively

\begin{tabular}{|c|c|c|c|c|}
\hline Hahn 2008 & 20 & $\begin{array}{l}\text { Spinal fixa- } \\
\text { tion with pedi- } \\
\text { cle-screw- } \\
\text { alone con- } \\
\text { structs }\end{array}$ & $\begin{array}{l}\text { Percentage of } \\
\text { predicted FVC } \\
\text { (\%FVC), Cobb } \\
\text { angle, degree } \\
\text { of pelvic tilt, } \\
\text { lumbar lordo- } \\
\text { sis and tho- } \\
\text { racic kypho- } \\
\text { sis, mortality, } \\
\text { complications }\end{array}$ & $\begin{array}{l}\text { Cobb angle improved from } 44^{\circ} \text { to } 10^{\circ} \text {, pelvic } \\
\text { tilt improved from } 14^{\circ} \text { to } 3^{\circ} \text {. Lumbar lordosis } \\
\text { improved from } 20^{\circ} \text { to } 49^{\circ} \text {, thoracic kypho- } \\
\text { sis remained unchanged. No problems relat- } \\
\text { ed to iliac fixation, no pseudarthrosis or im- } \\
\text { plant failures. No pulmonary complications. } \\
\% \text { FVC decreased from } 55 \% \text { preoperatively } \\
\text { to } 44 \% \text { at the last follow-up. } 1 \text { patient died } \\
\text { intraoperatively due to a sudden cardiac ar- } \\
\text { rest }\end{array}$ \\
\hline
\end{tabular}

\begin{tabular}{|c|c|c|c|c|c|}
\hline Harper 2004 & 45 & $\begin{array}{l}\text { AO Universal } \\
\text { Spinal Sys- } \\
\text { tem insert- } \\
\text { ed through a } \\
\text { posterior ap- } \\
\text { proach }\end{array}$ & $\begin{array}{l}\text { Mortality, } \\
\text { complica- } \\
\text { tions, hospital } \\
\text { stay }\end{array}$ & $\begin{array}{l}\text { No significant difference in operative and } \\
\text { postoperative outcomes between patients } \\
\text { with preoperative FVC }>30 \% \text { and } \leq 30 \% \text {. } \\
\text { Complications in } 9 \text { patients: pneumonia, } \\
\text { respiratory failure requiring tracheostomy, } \\
\text { ARDS, pleural effusion, cardiac arrhythmia }\end{array}$ & $\begin{array}{l}\text { Concluded } \\
\text { that routine } \\
\text { postoperative } \\
\text { use of mask } \\
\text { ventilation to } \\
\text { facilitate ear- } \\
\text { ly tracheal ex- } \\
\text { tubation was } \\
\text { vital }\end{array}$ \\
\hline
\end{tabular}

\begin{tabular}{|c|c|c|c|c|}
\hline Heller 2001 & 31 & Isola system & $\begin{array}{l}\text { Cobb angle, } \\
\text { pelvic obliqui- } \\
\text { ty, mortality, } \\
\text { complications }\end{array}$ & $\begin{array}{l}\text { Cobb angle decreased from } 48.6^{\circ} \text { to } 12.5^{\circ} \text {, } \\
\text { pelvic obliquity decreased from } 18.2^{\circ} \text { to } 3.8^{\circ} \text {. } \\
1 \text { postoperative death due to cardiac failure. } \\
\text { Complications: pneumonia (1), respirato- } \\
\text { ry arrest (1), pneumothorax (1), respiratory } \\
\text { failure requiring tracheostomy (1), disloca- } \\
\text { tion of hook (2), infection requiring revision } \\
\text { surgery (5), iliac vein thrombosis (1), mas- } \\
\text { sive bleeding (1) }\end{array}$ \\
\hline
\end{tabular}

\begin{tabular}{|c|c|c|c|c|c|}
\hline Hopf 1994 & 20 & $\begin{array}{l}\text { Multi-segmen- } \\
\text { tal instrumen- } \\
\text { tation }\end{array}$ & $\begin{array}{l}\text { Mortality, } \\
\text { complica- } \\
\text { tions, Cobb } \\
\text { angle }\end{array}$ & $\begin{array}{l}\text { Mean Cobb angle decreased from } 70.6^{\circ} \text { to } \\
31.2^{\circ} \text { (mean correction } 39.4^{\circ} \text { or } 55.8 \% \text { ). Lor- } \\
\text { dosis of the lumbar spine corrected from } \\
4.1^{\circ} \text { to } 17.8^{\circ} \text {. No perioperative mortality. } \\
\text { Complication: bladder dysfunction in } 1 \text { pa- } \\
\text { tient }\end{array}$ & $\begin{array}{l}\text { Recommend- } \\
\text { ed using mul- } \\
\text { ti-segmental } \\
\text { instrumen- } \\
\text { tation meth- } \\
\text { ods to enable } \\
\text { rapid mobi- } \\
\text { lization and a } \\
\text { postoperative } \\
\text { care without } \\
\text { brace or cast }\end{array}$ \\
\hline
\end{tabular}


Table 1. Characteristics of excluded studies (Continued)

\begin{tabular}{|c|c|c|c|c|}
\hline Kennedy 1995 & 38 & $\begin{array}{l}\text { Surgery (17), } \\
\text { no surgery } \\
(21)\end{array}$ & $\begin{array}{l}\text { Cobb angle, } \\
\text { FVC, mortality }\end{array}$ & $\begin{array}{l}\text { Mean Cobb angle of the surgical group at } \\
14.9 \text { years was } 57+/-16.4^{\circ} \text {, and of the non- } \\
\text { surgical group at } 15 \text { years was } 45+/-9.9^{\circ} \text {. } \\
\text { No difference in the rate of deterioration of } \\
\% \text { FVC, which was } 3 \% \text { to } 5 \% \text { per year. No dif- } \\
\text { ference in survival between groups }\end{array}$ \\
\hline
\end{tabular}

Spinal stabilization in DMD did not alter the decline in pulmonary function or improve survival

\begin{tabular}{|c|c|c|c|c|}
\hline Kinali 2006 & 123 & $\begin{array}{l}\text { Surgery }(43) \\
\text { no surgery } \\
(80)\end{array}$ & $\begin{array}{l}\text { Survival, FVC, } \\
\text { sitting com- } \\
\text { fort }\end{array}$ & $\begin{array}{l}\text { No difference in survival, respiratory impair- } \\
\text { ment, or sitting comfort between patients } \\
\text { managed conservatively and those who had } \\
\text { surgery }\end{array}$ \\
\hline
\end{tabular}

\begin{tabular}{|c|c|c|c|c|c|}
\hline Laprade 1992 & 9 & $\begin{array}{l}\text { Sublaminar } \\
\text { wiring (4), in- } \\
\text { traspinous } \\
\text { segmental } \\
\text { wiring (5) }\end{array}$ & $\begin{array}{l}\text { Mortality, } \\
\text { complica- } \\
\text { tions, oper- } \\
\text { ative time, } \\
\text { blood loss, } \\
\text { Cobb angle }\end{array}$ & $\begin{array}{l}\text { Operative time and blood loss lower in sub- } \\
\text { laminar compared to intraspinous wiring. } \\
\text { Allogeneic bone grafts to supplement the } \\
\text { autogenous bone graft allowed for extensive } \\
\text { fusion. } \\
\text { Cobb angle decreased by a mean of } 32^{\circ} \text {. } \\
\text { Complications: dural leak (1), transient } \\
\text { numbness of left foot (1), dislodgement of } \\
\text { sacral alar hooks (2). }\end{array}$ & $\begin{array}{l}\text { Recommend- } \\
\text { ed segmental } \\
\text { fusion and al- } \\
\text { logeneic bone } \\
\text { grafts }\end{array}$ \\
\hline
\end{tabular}

\begin{tabular}{|c|c|c|c|c|}
\hline Marchesi 1997 & 25 & $\begin{array}{l}\text { Modified } \\
\text { Luque: sacral } \\
\text { screws in each } \\
\text { S-1 pedicle } \\
\text { and a device } \\
\text { for transverse } \\
\text { traction be- } \\
\text { tween the } \\
\text { caudal right- } \\
\text { angle bends of } \\
\text { the L-rods }\end{array}$ & $\begin{array}{l}\text { Cobb angle, } \\
\text { pelvic obliqui- } \\
\text { ty, mortality, } \\
\text { instrumental } \\
\text { failure, sitting } \\
\text { balance }\end{array}$ & $\begin{array}{l}\text { Cobb angle decreased from } 68^{\circ} \text { to } 18^{\circ} \text {, pelvic } \\
\text { obliquity decreased from } 21^{\circ} \text { to }<15^{\circ} \text { with } \\
\text { mean correction of } 75 \% \text {. No instrumenta- } \\
\text { tion failure or loss of correction }>3^{\circ} \text {. A good } \\
\text { sitting balance could be restored in every } \\
\text { patient. No perioperative mortality }\end{array}$ \\
\hline
\end{tabular}

\begin{tabular}{lll}
\hline Marsh $2003 \quad 30$ & $\begin{array}{l}\text { Posterior } \\
\text { spinal fusion }\end{array}$
\end{tabular}

Cobb angle,
mortality,
complica-
tions, hospital
stay
Mean correction of Cobb angle $36^{\circ} .2$ sub- groups of patients were compared: those with more than $30 \%$ preoperative FVC ( 17 patients) and those with less than $30 \%$ pre- operative FVC (13 patients). There were 9 complications in total, with 1 patient in each group requiring a temporary tracheosto- my. The postoperative stay for patients in each group was similar ( 24 days in the $>30 \%$ group, 20 days in the $<30 \%$ group), and the complication rate was comparable with oth- er published series. No perioperative mor- tality

Recommendmental logeneic bone grafts
Concluded that spinal fusion could be offered to patients with DMD even in the presence of a low FVC

\begin{tabular}{lll}
\hline Matsumura $\quad 8$ & Luque rod & Cobb angle, \\
1997 & (2), Cotrel- & FVC, quality \\
Dubousset rod & of life, mortal- \\
& (6) & ity, complica- \\
& tions, sitting \\
& balance
\end{tabular}

Cobb angle corrected from $58.8^{\circ}$ to $28.6^{\circ}$ with a mean corrective rate of $51.3 \%$. FVC increased in 3 patients with moderate scoliosis (Cobb angle: $50^{\circ}$ to $80^{\circ}$ ). 2 cases with low $\%$ FVC (16.9\% and $30.4 \%$, respectively) had poor prognosis in respiratory status. 1 died of pneumonia at 17 months after surgery, and the other required mechanical ventilation. Sitting balance improved in all patients
Recommended spinal fusion for patients with Cobb angle more than $30^{\circ}$ and with \%FVC more than $35 \%$. Al- 
Table 1. Characteristics of excluded studies (Continued)

though the impact of spinal fusion upon life expectancy remained unclear, favorable effects on respiratory function and quality of life could be expected for carefully selected patients with DMD

\begin{tabular}{|c|c|c|c|c|c|}
\hline Mehdian 1989 & 17 & $\begin{array}{l}\text { Luque rods se- } \\
\text { cured by con- } \\
\text { ventional sub- } \\
\text { laminar wires } \\
\text { (9), Luque } \\
\text { rods secured } \\
\text { by sublaminar } \\
\text { nylon straps } \\
\text { (4), } 2 \text { L-shaped } \\
\text { rods connect- } \\
\text { ed by H-bars } \\
\text { secured by } \\
\text { closed wire } \\
\text { loops (3), } \\
\text { Hartshill rec- } \\
\text { tangle and } \\
\text { sublaminar } \\
\text { wires (1) }\end{array}$ & $\begin{array}{l}\text { Cobb angle, } \\
\text { respiratory } \\
\text { function }\end{array}$ & $\begin{array}{l}\text { Significant loss of correction in Luque rods } \\
\text { secured by sublaminar nylon straps and } \\
\text { Hartshill system } \\
\text { Strong correlation between advance of sco- } \\
\text { liosis and respiratory function }\end{array}$ & \\
\hline Miller 1988 & 67 & $\begin{array}{l}\text { Surgery }(21) \text {, } \\
\text { no surgery } \\
(46)\end{array}$ & FVC & $\begin{array}{l}\text { No difference was found in the rate of deteri- } \\
\text { oration of the percentage of normal FVC }\end{array}$ & \\
\hline Miller 1991 & 39 & $\begin{array}{l}\text { Surgery (17), } \\
\text { no surgery } \\
(22)\end{array}$ & $\begin{array}{l}\text { Respiratory } \\
\text { function, sit- } \\
\text { ting comfort, } \\
\text { sitting appear- } \\
\text { ance }\end{array}$ & $\begin{array}{l}\text { No significant differences in terms of declin- } \\
\text { ing respiratory function. All operated pa- } \\
\text { tients reported either improved sitting com- } \\
\text { fort, appearance, or both }\end{array}$ & $\begin{array}{l}\text { Concluded } \\
\text { distinct bene- } \\
\text { fits from seg- } \\
\text { mental spine } \\
\text { fusion; how- } \\
\text { ever, no salu- } \\
\text { tary effect up- } \\
\text { on respirato- } \\
\text { ry function } \\
\text { either in the } \\
\text { short term } \\
\text { or after up to } \\
5 \text { years' fol- } \\
\text { low-up }\end{array}$ \\
\hline Miller 1992 & $\begin{array}{l}183 \text { ( } 87 \text { fol- } \\
\text { lowed up to } \\
\text { death) }\end{array}$ & $\begin{array}{l}\text { Surgery (68), } \\
\text { no surgery } \\
(115)\end{array}$ & $\begin{array}{l}\text { Survival, pa- } \\
\text { tient com- } \\
\text { fort, ease of } \\
\text { care, respira- }\end{array}$ & $\begin{array}{l}\text { Patients with surgery were more comfort- } \\
\text { able in the later years of life and easier to } \\
\text { care for, but spinal fusion did not affect } \\
\text { deteriorating pulmonary function. Age at }\end{array}$ & \\
\hline
\end{tabular}


tory function, death for the 29 boys who underwent spinal quality of life fusion was 18.3 years, similar to that of the 58 boys without surgery. Factors that improved the patients' quality of life included segmental instrumentation, fusion from $\mathrm{T} 2$ to the pelvis, correcting or balancing scoliosis, creating normal sagittal plane alignment, and correcting pelvic obliquity

\begin{tabular}{llll}
\hline Modi 2008a & 26 (including 7 & posterior & Cobb angle, \\
& cerebral palsy, & pelvic screw & pelvic obliqui- \\
& 5 SMA, 4 oth- & fixation & ty, complica- \\
& ers) & & tions
\end{tabular}

Mean Cobb angle: $78.53^{\circ}$ (before surgery), $30.7^{\circ}$ (after surgery), $33.06^{\circ}$ (final follow-up). There was no difference in the percentage correction between the group with $>90^{\circ}$ and the group with $<90^{\circ}$. Complications: 1 transient loss of lower limb power, 1 deep wound infection

\begin{tabular}{ll}
\hline Modi 2008b & 24 patients \\
& (including 6 \\
& cerebral pal- \\
& sy, 5 SMA, 4 \\
& others) and 12 \\
& controls (ado- \\
& lescent idio- \\
& pathic scolio- \\
& sis)
\end{tabular}

$\begin{array}{lll}\text { Posterior } & \text { Cobb angle, } \\ \text { pedicle screw } & \begin{array}{l}\text { Mean Cobb angle decreased from } 74^{\circ} \text { to } 32^{\circ} . \\ \text { ty, apical rota- } \\ \text { tion }\end{array} & \begin{array}{l}\text { Mean pelvic obliquity decreased from } 14^{\circ} \\ \text { to } 6^{\circ} . \text { Mean apical rotation decreased from } \\ 42^{\circ} \text { to } 33^{\circ} \text {. There was no significant differ- } \\ \text { ence between different patient groups or } \\ \text { between patients and controls }\end{array}\end{array}$

\begin{tabular}{llll}
\hline Modi 2009 & 50 (including & Posterior & Mortality, \\
18 patients & spinal fusion & complica- \\
with cerebral & with segmen- & tions, Cobb \\
palsy, 8 with & tal spinal in- & angle, pelvic \\
SMA, and 6 & strumentation & obliquity \\
others) & using pedicle & \\
& & screw fixation &
\end{tabular}

Cobb angle decreased from $79.3+/-30.3^{\circ}$ to $31.3+/-21.6^{\circ}$. Pelvic obliquity decreased from $14.6+/-9.4^{\circ}$ to $6.8+/-6.3^{\circ} .2$ deaths $(1$ due to cardiac arrest, 1 due to hypovolemic shock. 34 patients had at least 1 perioperative complication (16 pulmonary, 14 abdominal, 3 wound related, 2 neurological, 1 cardiovascular). Postoperative complications: 7 coccygodynia, 3 screw head prominence, 2 bedsore, 1 implant loosening

\begin{tabular}{|c|c|c|c|c|c|}
\hline Modi 2010 & $\begin{array}{l}55 \text { (including } \\
28 \text { patients } \\
\text { with cerebral } \\
\text { palsy and } 10 \\
\text { with SMA) }\end{array}$ & $\begin{array}{l}\text { Spinal fixation } \\
\text { from T2/T3/ } \\
\text { T4 to L4/L5 } \\
\text { with or with- } \\
\text { out pelvic fix- } \\
\text { ation. Group } \\
\text { 1: pelvic obliq- } \\
\text { uity }>15^{\circ} \text { with } \\
\text { pelvic fixation; } \\
\text { group 2: pelvic } \\
\text { obliquity }> \\
15^{\circ} \text { without } \\
\text { pelvic fixation; } \\
\text { group 3: pelvic } \\
\text { obliquity < } 15^{\circ} \\
\text { without pelvic } \\
\text { fixation }\end{array}$ & $\begin{array}{l}\text { Cobb angle, } \\
\text { pelvic obliqui- } \\
\text { ty, complica- } \\
\text { tions }\end{array}$ & $\begin{array}{l}\text { Mean correction of Cobb angle after oper- } \\
\text { ation: group } 1: 43.8^{\circ} ; \text { group } 2: 40^{\circ} \text {; group } 3 \text { : } \\
48.7^{\circ} \text {. Mean loss of correction of Cobb angle } \\
\text { at last follow-up: group } 1: 0.6^{\circ} \text {; group } 2: 2.3^{\circ} \text {; } \\
\text { group } 3: 3^{\circ} \text {. Mean correction of pelvic obliq- } \\
\text { uity: group } 1: 14.4^{\circ} ; \text { group } 2: 10.7^{\circ} \text {; group } 3 \text { : } \\
5^{\circ} \text {. Mean loss of correction of pelvic obliq- } \\
\text { uity at last follow-up: group } 1:-0.6^{\circ} \text {; group } \\
2: 6.5^{\circ} \text {; group } 3: 0.8^{\circ} \text {. Group } 2 \text { showed signif- } \\
\text { icant loss of pelvic obliquity compared to } \\
\text { group } 1 \text {. Complications: } 3 \text { patients in group } \\
1 \text { had sacral sores }\end{array}$ & $\begin{array}{l}\text { Patients who } \\
\text { have pelvic } \\
\text { obliquity > } \\
15^{\circ} \text { require } \\
\text { pelvic fixation } \\
\text { to maintain } \\
\text { correction }\end{array}$ \\
\hline Mubarak 1993 & 22 & $\begin{array}{l}\text { Luque seg- } \\
\text { mental instru- } \\
\text { mentation } \\
\text { and fusion in- }\end{array}$ & $\begin{array}{l}\text { Cobb angle, } \\
\text { pelvic obliqui- } \\
\text { ty }\end{array}$ & Outcomes similar between the 2 groups & $\begin{array}{l}\text { Concluded } \\
\text { that if treat- } \\
\text { ment is ini- } \\
\text { tiated ear- }\end{array}$ \\
\hline
\end{tabular}

Surgery for scoliosis in Duchenne muscular dystrophy (Review)

Copyright @ 2015 The Cochrane Collaboration. Published by John Wiley \& Sons, Ltd.
DMD patients had higher risk of postoperative coccygodynia 
Table 1. Characteristics of excluded studies (Continued)

strumented

to the sacro-

ly, Luque in-

pelvis (12), in-

strumenta-

strumented to

tion and fu-

L5 (10)

sion from high

thoracic (T2 or

T3) to the 5th

lumbar verte-

bra should be

sufficient

\begin{tabular}{|c|c|c|c|c|}
\hline $\begin{array}{l}\text { Nakazawa } \\
2010\end{array}$ & 36 & $\begin{array}{l}\text { Autogenous } \\
\text { bone graft } \\
\text { (20), allogene- } \\
\text { ic bone graft } \\
(16)\end{array}$ & $\begin{array}{l}\text { Cobb angle, } \\
\text { operating } \\
\text { time, blood } \\
\text { loss }\end{array}$ & $\begin{array}{l}\text { No difference in Cobb angle between the } 2 \\
\text { groups. Mean operating time longer in auto- } \\
\text { genous group ( } 253 \mathrm{~min} \text { ) compared to alloge- } \\
\text { nous group ( } 233 \mathrm{~min}) \text {. Mean blood loss high- } \\
\text { er in autogenous group ( } 850 \mathrm{ml} \text { ) compared } \\
\text { to allogenous group }(775 \mathrm{ml} \text { ) }\end{array}$ \\
\hline
\end{tabular}

$90 \%$ and $50 \%$

of patients in

autogenous

group report-

ed donor site

pain after 1

week and 3

months, re-

spectively.

Concluded

against auto-

genous bone

graft for scol-

iosis surgery

in DMD pa-

tients

\begin{tabular}{|c|c|c|c|c|c|}
\hline Rice 1998 & 19 & $\begin{array}{l}\text { Long spinal } \\
\text { fusion to L5 } \\
\text { and ongoing } \\
\text { wheelchair } \\
\text { seating atten- } \\
\text { tion }\end{array}$ & $\begin{array}{l}\text { Sitting posi- } \\
\text { tion }\end{array}$ & $\begin{array}{l}\text { At long-term follow-up, } 15 \text { patients contin- } \\
\text { ued to sit in a well-balanced position }\end{array}$ & $\begin{array}{l}\text { Concluded } \\
\text { that surgi- } \\
\text { cal fusion of } \\
\text { the spine to } \\
\text { L5 combined } \\
\text { with ongoing } \\
\text { attention to } \\
\text { seating was } \\
\text { associated } \\
\text { with good } \\
\text { long-term } \\
\text { functional re- } \\
\text { sults in these } \\
\text { patients }\end{array}$ \\
\hline Rideau 1984 & 5 & $\begin{array}{l}\text { Luque seg- } \\
\text { mental spinal } \\
\text { stabilisation } \\
\text { without bone } \\
\text { fusion }\end{array}$ & $\begin{array}{l}\text { Cobb angle, } \\
\text { vital capac- } \\
\text { ity, mortali- } \\
\text { ty, complica- } \\
\text { tions, hospi- } \\
\text { tal stay, pelvic } \\
\text { obliquity, pa- } \\
\text { tient comfort }\end{array}$ & $\begin{array}{l}\text { Cobb angle decreased from } 27^{\circ} \text { to } 11^{\circ} \text {. Pelvic } \\
\text { obliquity partially reduced. Static vital ca- } \\
\text { pacity after } 2 \text { years. No perioperative mor- } \\
\text { tality, } 1 \text { bronchopneumonia. All patients } \\
\text { more comfortable during wheelchair activi- } \\
\text { ties }\end{array}$ & $\begin{array}{l}\text { Concluded } \\
\text { that surgical } \\
\text { intervention } \\
\text { should be un- } \\
\text { dertaken pro- } \\
\text { phylactically } \\
\text { when there is } \\
\text { high risk of a } \\
\text { rapidly evolv- } \\
\text { ing curve with } \\
\text { a severe re- } \\
\text { strictive lung } \\
\text { syndrome }\end{array}$ \\
\hline Sakai 1977 & 41 & $\begin{array}{l}\text { Surgery }(10) \\
\text { no surgery } \\
(31)\end{array}$ & $\begin{array}{l}\text { Sitting stabili- } \\
\text { ty, mortality, } \\
\text { complications }\end{array}$ & $\begin{array}{l}\text { Pulmonary complications were minimized } \\
\text { by performing preoperative tracheotomy } \\
\text { on all patients who had vital capacities less } \\
\text { than } 40 \% \text { or non-functional coughs, or both. }\end{array}$ & \\
\hline
\end{tabular}


No perioperative mortality. Spinal fusion permitted long-term sitting stability despite the progression of the disease

\begin{tabular}{|c|c|c|}
\hline \multirow[t]{2}{*}{$\begin{array}{l}\text { Sengupta } \\
2002\end{array}$} & 50 & $\begin{array}{l}\text { Pelvic fixation: } \\
\text { Galveston } \\
\text { technique (9), } \\
\text { L-rod (22) }\end{array}$ \\
\hline & & $\begin{array}{l}\text { Lumbar fixa- } \\
\text { tion: pedicle } \\
\text { screw + sub- } \\
\text { laminar wires } \\
\text { (19) }\end{array}$ \\
\hline
\end{tabular}

Cobb angle, pelvic obliquity, mortality, complications, hospital stay (19)
In the pelvic fixation group, the mean Cobb angle and pelvic obliquity were $48^{\circ}$ and $19.8^{\circ}$ at the time of surgery, $16.7^{\circ}$ and $7.2^{\circ}$ immediately after surgery, and $22^{\circ}$ and $11.6^{\circ}$ at the final follow-up (mean 4.6 years). The mean hospital stay was 17 days. 5 major complications: deep wound infection (1), revision of instrumentation prominence at the proximal end (2), loosening of pelvic fixation (2). In the lumbar fixation group, the mean Cobb angle and pelvic obliquity were $19.8^{\circ}$ and $9^{\circ}$ at the time of surgery, $3.2^{\circ}$ and $2.2^{\circ}$ immediately after surgery, and $5.2^{\circ}$ and $2.9^{\circ}$ at the final follow-up (mean 3.5 years). The mean hospital stay ( 7.7 days) was much less compared with the pelvic fixation group. Pelvic obliquity was corrected and maintained below $10^{\circ}$ in all but 2 cases, who had an initial pelvic obliquity exceeding $20^{\circ} .2$ complications: instrumentation failure at the proximal end (1), deep wound infection (1). No perioperative mortality

\begin{tabular}{|c|c|c|c|c|c|}
\hline Shapiro 1992 & 27 & $\begin{array}{l}\text { Harrington } \\
\text { rod (2), Har- } \\
\text { rington rod } \\
\text { with sublami- } \\
\text { nar wires ( } 7 \text { ), } \\
\text { Harrington } \\
\text { rod, Luque } \\
\text { rod, and } 2 \\
\text { double sub- } \\
\text { laminar wires } \\
\text { at each level } \\
(17)\end{array}$ & $\begin{array}{l}\text { Cobb angle, } \\
\text { FVC, mortali- } \\
\text { ty, complica- } \\
\text { tions }\end{array}$ & $\begin{array}{l}1 \text { sudden cardiac arrest and died intraoper- } \\
\text { atively. } 3 \text { intraoperative complications re- } \\
\text { versed without sequelae. Mean postopera- } \\
\text { tive correction } 13.1+/-11.9^{\circ} \text {, with mean loss } \\
\text { of correction } 5.1+/-3.1^{\circ} \text { at } 2.4+/-1.8 \text { years. } \\
\text { Mean FVC preoperatively was } 45.3+/-15.9 \% \\
\text { with continuing diminution to } 28.7+/-14.9 \% \\
\text { at } 3.3+/-2.2 \text { years after surgery }\end{array}$ & $\begin{array}{l}\text { Concluded } \\
\text { that the main } \\
\text { benefit of sur- } \\
\text { gical stabilisa- } \\
\text { tion was the } \\
\text { relative ease } \\
\text { and comfort } \\
\text { of wheelchair } \\
\text { seating com- } \\
\text { pared with } \\
\text { those non- } \\
\text { operated pa- } \\
\text { tients who de- } \\
\text { veloped pro- } \\
\text { gressive de- } \\
\text { formity. No } \\
\text { lasting im- } \\
\text { provement or } \\
\text { stabilisation } \\
\text { in FVC follow- } \\
\text { ing surgery } \\
\text { as decreasing } \\
\text { function was } \\
\text { related pri- } \\
\text { marily to mus- } \\
\text { cle weakness }\end{array}$ \\
\hline Stricker 1996 & $\begin{array}{l}46 \text { (included } \\
\text { other neuro- } \\
\text { muscular dis- } \\
\text { eases) }\end{array}$ & $\begin{array}{l}\text { Modified } \\
\text { Luque tech- } \\
\text { nique }\end{array}$ & $\begin{array}{l}\text { Cobb angle, } \\
\text { complications }\end{array}$ & $\begin{array}{l}\text { Cobb angle decreased from } 63^{\circ} \text { to } 24^{\circ} \text { (cor- } \\
\text { rection of about } 62 \% \text { ). Failure of implants, } \\
\text { pseudarthroses, and major losses of cor- } \\
\text { rection in purely neuromuscular scolioses } \\
\text { could be avoided by using rigid segmental }\end{array}$ & $\begin{array}{l}\text { Concluded } \\
\text { that the best } \\
\text { method of } \\
\text { treatment } \\
\text { in DMD is } \\
\text { surgery per- }\end{array}$ \\
\hline
\end{tabular}


Table 1. Characteristics of excluded studies (Continued)

fixation and a dorsolateral fusion with a mixture of autologous and allogenous bone formed as early as possible, i.e. at the time of loss of walking capacity in the case of a scoliosis exceeding $20^{\circ}$ and with 2 consecutive X-rays proving curve progression

Suk 2014 $66 \quad \begin{aligned} & \text { Surgery } \\ & (40), \text { refused } \\ & \text { surgery (26) }\end{aligned}$

Cobb angle,
lordosis an-
gle, pelvic
obliquity, $\mathrm{FVC}$,
end-tidal $\mathrm{CO}_{2}$,
use of NIPPV,
functional sta-
tus (assessed
by manual
muscle test,
modified Ran-
cho Scale, and
MDSQ)
surgical group $(3.9+/-0.3)$ and the non-surgical group (4.04+/-0.3). Significantly higher mean MDSQ score in the surgical group (35.1 $+/$ 14.7) compared with the non-surgical group (26.9+/-9.9). Significantly lower mean deterioration in FVC after 2 years in the surgical group $(268+/-361 \mathrm{ml})$ compared with the non-surgical group $(536+/-323 \mathrm{ml})$. No significant difference in mean $\mathrm{pCO}_{2}$ between the surgical group $(38.4+/-5.5 \mathrm{mmHg})$ and the non-surgical group $(39.4+/-6.7 \mathrm{mmHg})$. No significant difference in the use of NIPPV between the surgical group (80\%) and the non-surgical group (88\%)

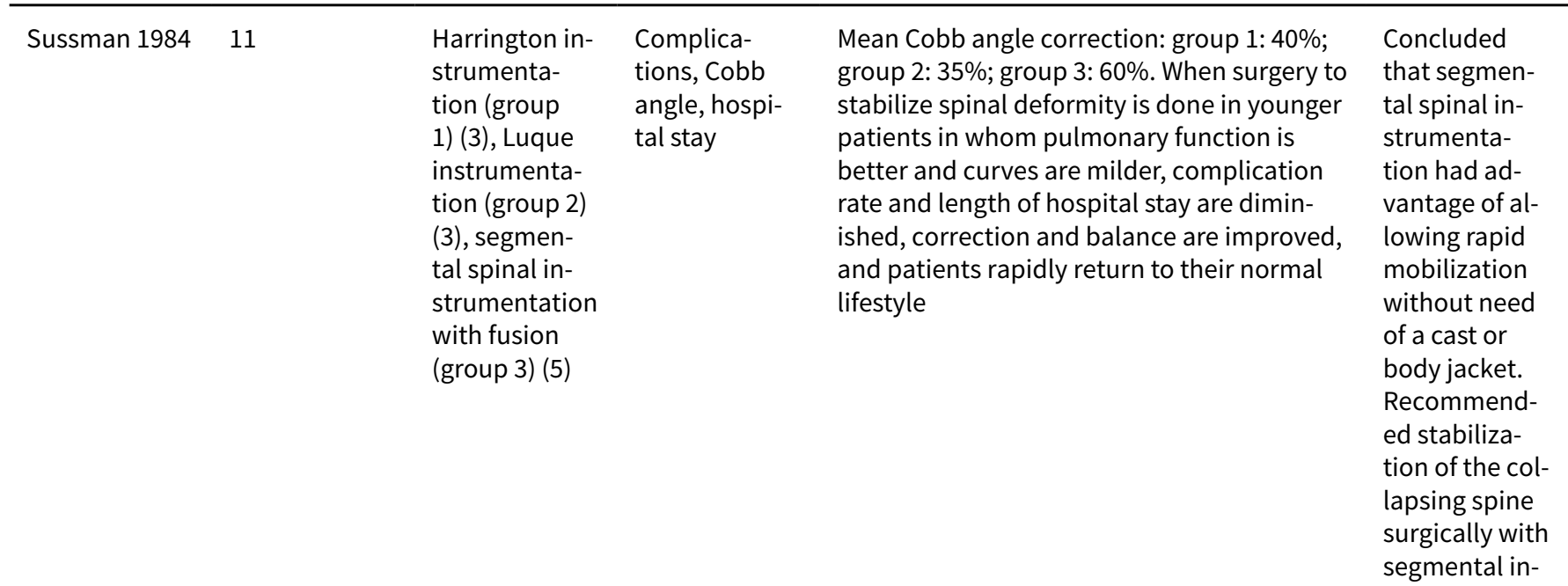


Table 1. Characteristics of excluded studies (Continued)

strumentation and fusion

when scoliosis reached $30^{\circ}$ to $40^{\circ}$

\begin{tabular}{|c|c|c|c|c|c|}
\hline Takaso 2010 & 20 & $\begin{array}{l}\text { Segmental } \\
\text { pedicle screws } \\
\text { instrumenta- } \\
\text { tion and fu- } \\
\text { sion to L5 }\end{array}$ & $\begin{array}{l}\text { Cobb angle, } \\
\text { pelvic obliqui- } \\
\text { ty, operating } \\
\text { time, blood } \\
\text { loss, compli- } \\
\text { cations }\end{array}$ & $\begin{array}{l}\text { Mean Cobb angle decreased from } 70^{\circ} \text { to } 15^{\circ} \text {. } \\
\text { Mean pelvic obliquity decreased from } 13^{\circ} \text { to } \\
6^{\circ} \text {. Mean intraoperative blood loss was } 890 \\
\mathrm{ml} \text { (range: } 660 \text { to } 1260 \mathrm{ml} \text { ). Mean total blood } \\
\text { loss was } 2100 \mathrm{ml} \text { (range: } 1250 \text { to } 2880 \mathrm{ml} \text { ). } \\
\text { No major complications }\end{array}$ & \\
\hline Thacker 2002 & $\begin{array}{l}\text { 24, of whom } 5 \\
\text { had DMD }\end{array}$ & $\begin{array}{l}\text { Not detailed } \\
\text { in DMD pa- } \\
\text { tients }\end{array}$ & $\begin{array}{l}\text { FEV1, FVC, } \\
\text { mortality, } \\
\text { complications }\end{array}$ & $\begin{array}{l}\text { FVC and FEV1 maintained, pseudarthrosis in } \\
1 \text { patient, no perioperative mortality }\end{array}$ & $\begin{array}{l}\text { Included } 7 \\
\text { SMA, } 6 \text { spastic } \\
\text { cerebral pal- } \\
\text { sy, } 3 \text { congeni- } \\
\text { tal myopathy, } \\
2 \text { spina bifida, } \\
1 \text { paraspinal } \\
\text { neuroblas- } \\
\text { toma in the } \\
\text { series }\end{array}$ \\
\hline Velasco 2007 & 56 & $\begin{array}{l}\text { Posterior } \\
\text { spinal fusion }\end{array}$ & $\begin{array}{l}\text { Percent nor- } \\
\text { mal FVC }\end{array}$ & $\begin{array}{l}\text { The rates of FVC decline were } 4 \% \text { per year } \\
\text { presurgery, which decreased to } 1.75 \% \text { per } \\
\text { year postsurgery }\end{array}$ & \\
\hline $\begin{array}{l}\text { Weimann } \\
1983\end{array}$ & 24 & $\begin{array}{l}\text { Long Harring- } \\
\text { ton instru- } \\
\text { mentations } \\
\text { and spinal fu- } \\
\text { sions from S1 } \\
\text { up to the up- } \\
\text { per thoracic } \\
\text { spine (T4, 5, or } \\
\text { 6) }\end{array}$ & $\begin{array}{l}\text { Mortality, } \\
\text { complications }\end{array}$ & $\begin{array}{l}1 \text { patient died } 2 \text { years after his operation } \\
\text { from dystrophic cardiomyopathy }\end{array}$ & $\begin{array}{l}\text { Concluded } \\
\text { that prophy- } \\
\text { lactic spinal } \\
\text { fusion de- } \\
\text { served con- } \\
\text { sideration for } \\
\text { these patients }\end{array}$ \\
\hline
\end{tabular}

ARDS: adult respiratory distress syndrome;

DMD: Duchenne muscular dystrophy;

FEV1: forced expiratory volume in 1 second;

FVC: forced vital capacity;

MDSQ: Muscular Dystrophy Spine Questionnaire;

NIPPV: non-invasive positive pressure ventilation;

PEFR: peak expiratory flow rate;

SMA: spinal muscular atrophy

\section{A P PE N D I CES}

\section{Appendix 1. MEDLINE strategy}

Database: Ovid MEDLINE(R) <1946 to June Week $12015>$

Search Strategy:

1 randomized controlled trial.pt. (396862)

2 controlled clinical trial.pt. (89648)

3 randomized.ab. (293733)

4 placebo.ab. (152857) 
5 drug therapy.fs. (1782093)

6 randomly.ab. (207091)

7 trial.ab. (303153)

8 groups.ab. (1318490)

9 or/1-8 (3363492)

10 exp animals/ not humans.sh. (4057817)

119 not 10 (2863375)

12 surg\$.mp. or surgery/ (1563766)

13 spine $\$ . m p$. (98598)

14 spinal.mp. (299674)

15 vertebra\$.mp. (190697)

16 or/13-15 (465197)

1712 and 16 (67662)

18 spinal fusion/ or spinal fusion.mp. (18917)

1917 or $18(74660)$

20 scolio\$.mp. or Scoliosis/ (17344)

21 duchenne.mp. or Muscular Dystrophy, Duchenne/ (8935)

2211 and 19 and 20 and 21 (23)

23 remove duplicates from 22 (22)

\section{Appendix 2. EMBASE search strategy}

Database: Embase <1980 to 2015 Week 24>

Search Strategy:

1 crossover-procedure.sh. (43171)

2 double-blind procedure.sh. (121038)

3 single-blind procedure.sh. (20388)

4 randomized controlled trial.sh. (373903)

5 (random\$ or crossover\$ or cross over\$ or placebo $\$$ or (doubl\$ adj blind\$) or allocat\$).tw,ot. (1149602)

6 trial.ti. (178538)

7 clinical trial/ (845836)

8 or/1-7 (1754858)

9 (animal/ or nonhuman/ or animal experiment/) and human/ (1373553)

$10 \mathrm{animal} /$ or nonanimal/ or animal experiment/ (3397550)

1110 not 9 (2826709)

128 not $11(1647123)$

13 limit 12 to embase (1348090)

14 Surgery/ or surg\$.mp. (2399654)

15 (spine or spinal or vertebra\$).mp. (561465)

1614 and 15 (111605)

17 exp Spine Fusion/ (19893)

18 (spinal fusion or spine fusion).mp. (20513)

1916 or 17 or 18 (117843)

20 exp Scoliosis/ or scoliosis.mp. (24702)

21 Duchenne Muscular Dystrophy/ or duchenne.mp. (13075)

2213 and 19 and 20 and 21 (15)

\section{Appendix 3. CENTRAL search strategy}

\#1 MeSH descriptor General Surgery explode all trees

\#2 surgery

\#3 (\#1 OR \#2)

\#4 (spine or spinal or vertebra*)

\#5 (\#3 AND \#4)

\#6 MeSH descriptor Spinal Fusion, this term only

\#7 spinal fusion or spine fusion

\#8 (( \#5 AND \#6) OR \#7)

$\# 9$ scoliosis

\#10 duchenne

\#11(\#8 AND \#9 AND \#10) 


\section{Appendix 4. CINAHL Plus search strategy}

Tuesday, June 16, 2015 8:26:22 AM

S31 S29 AND S30 0

S30 EM 20141107- 203,432

S29 S18 and S28 15

S28 S25 and S26 and S27 43

S27 ("scoliosis") or (MH "Scoliosis") 5,070

S26 ("duchenne") or (MH "Duchenne Muscular Dystrophy") 1,105

S25 S22 or S24 19,231

S24 S23 or spinal fusion or spine fusion 5,799

S23 (MH "Spinal Fusion") 5,389

S22 S20 and S21 18,557

S21 spine or spinal or vertebra* 70,805

S20 S19 or surgery 302,370

S19 (MH "Surgery, Operative") 18,029

$\mathrm{S} 18 \mathrm{~S} 1$ or S2 or S3 or S4 or S5 or S6 or S7 or S8 or S9 or S10 or S11 or S12 or S13 or S14 or S15 or S16 or S17 752,583

S17 ABAB design* 93

S16 TI random* or AB random* 151,010

S15 ( TI (cross?over or placebo* or control* or factorial or sham? or dummy) ) or ( AB (cross?over or placebo* or control* or factorial or sham? or dummy) ) 301,434

S14 ( $\mathrm{TI}$ (clin* or intervention* or compar* or experiment* or preventive or therapeutic) or AB (clin* or intervention* or compar* or experiment ${ }^{\star}$ or preventive or therapeutic) ) and ( $\mathrm{TI}\left(\right.$ trial $\left.^{\star}\right)$ or AB (trial $\left.{ }^{\star}\right)$ ) 105,987

$\mathrm{S} 13$ ( $\mathrm{TI}$ (meta?analys* or systematic review*) ) or ( $\mathrm{AB}$ (meta?analys* or systematic review $\left.{ }^{\star}\right)$ ) 36,870

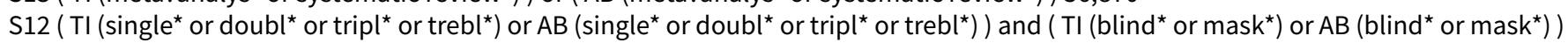
23,445

S11 PT ("clinical trial" or "systematic review") 127,929

S10 (MH "Factorial Design") 945

S9 (MH "Concurrent Prospective Studies") or (MH "Prospective Studies") 264,883

S8 (MH "Meta Analysis") 22,461

S7 (MH "Solomon Four-Group Design") or (MH "Static Group Comparison") 48

S6 (MH "Quasi-Experimental Studies") 7,381

S5 (MH "Placebos") 9,272

S4 (MH "Double-Blind Studies") or (MH "Triple-Blind Studies") 31,799

S3 (MH "Clinical Trials+") 188,614

S2 (MH "Crossover Design") 13,034

S1 (MH "Random Assignment") or (MH "Random Sample") or (MH "Simple Random Sample") or (MH "Stratified Random Sample") or (MH

"Systematic Random Sample") 69,594

\section{Appendix 5. ProQuest Dissertation \& Thesis database search strategy}

ProQuest Dissertations \& Theses Global

Your search for all(("spine fusion" OR "spinal fusion" OR (surgery NEAR/5 (spine OR vertebra*))) AND duchenne AND scoliosis AND (random* OR "double blind")) found 0 results.

\section{Appendix 6. Clinical trial registry databases}

Duchenne and surgery and scoliosis

\section{Appendix 7. Additional methods}

The following methods have been prespecified for use if studies eligible for inclusion are identified (Cheuk 2013).

\section{Data extraction and management}

We planned that two review authors ( $D C$ and VW) would independently extract data from included trials and enter data into a data collection form. We would have resolved all disagreements by consensus. We planned to contact authors of included studies to provide essential information missing from study reports. We would have extracted the following data:

\section{Study methods}

1. Design (e.g. randomized or quasi-randomized)

2. Randomization method (including list generation) 
3. Method of allocation concealment

4. Blinding method

5. Stratification factors

\section{Participants}

1. Inclusion/exclusion criteria

2. Number (total/per group)

3. Age distribution

4. Severity of scoliosis

5. Level of scoliosis

6. Baseline respiratory function

7. Associated morbidities, e.g. cardiomyopathy

8. Previous treatments, including corticosteroids

9. Pretreatment quality of life and functional status, as measured by validated scales

\section{Intervention and control}

1. Type of spinal surgery

2. Type of control

3. Details of control treatment including duration of non-operative treatment

4. Details of co-interventions

\section{Follow-up data}

1. Duration of follow-up

2. Loss to follow-up

\section{Outcome data as described above}

\section{Analysis data}

1. Methods of analysis (intention-to-treat/per-protocol analysis)

2. Comparability of groups at baseline (yes/no)

3. Statistical techniques

\section{Other}

1. Funding

2. Conflicts of interest among main investigators

The data were entered into Review Manager 5.3 (RevMan) (RevMan 2014).

\section{Assessment of risk of bias in included studies}

We planned to have two review authors (DC and VW) independently assess the risk of bias of each included study. We would resolve any disagreements by consensus. We planned to evaluate the risk of bias of included trials using the following criteria in accordance with the Cochrane Handbook for Systematic Reviews of Interventions (Higgins 2011):

\section{Selection bias}

1. Was allocation of participants to treatment and control groups randomized?

2. Was allocation concealed?

\section{Performance bias}

1. Were participants in the comparison groups treated differently apart from the study treatments?

2. Was there blinding of participants and personnel?

\section{Attrition bias}

1. Were there systematic differences between the comparison groups in the loss of participants from the study?

2. Were analyses by intention-to-treat? 


\section{Detection bias}

1. Were those assessing outcomes of the intervention blinded to the assigned intervention?

\section{Reporting bias}

1. Were there systematic differences between reported and unreported findings (incomplete outcome data)?

\section{Other bias}

1. Were there other issues that raise the possibility of bias, e.g. design-specific risks?

We planned to summarize the quality of a trial into one of three categories:

- Low risk of bias: all the validity criteria met.

- Moderate risk of bias: one or more validity criteria partly met, but none are not met.

- High risk of bias: one or more criteria not met.

\section{Measures of treatment effect}

We planned to use risk ratio estimations with 95\% confidence intervals (Cls) for binary outcomes. We planned to use mean difference estimations with $95 \%$ Cls for continuous outcomes. We planned to use hazard ratio estimations with 95\% Cls for time-to-event (survival) outcomes. All analyses would have included all participants in the treatment groups to which they were allocated.

\section{Dealing with missing data}

We planned to contact authors of included studies to supply missing data. We would have assessed missing data and dropouts (attrition) for each included study, and assessed and discussed the extent to which the results and conclusions of the review could be altered by the missing data. If, at the end of the trial, data for a particular outcome were available for less than $70 \%$ of participants allocated to the treatments, we would not have used those data, as we would have considered them to be too prone to bias.

\section{Assessment of heterogeneity}

We planned to assess clinical heterogeneity by comparing the distribution of important participant factors between trials (age, respiratory function, severity and level of scoliosis, associated diseases) and trial factors (allocation concealment, blinding of outcome assessment, losses to follow-up, treatment type, co-interventions). We would have assessed statistical heterogeneity by examining $\mathrm{I}^{2}$, a quantity that describes approximately the proportion of variation in point estimates that is due to heterogeneity rather than sampling error (Higgins 2002). In addition, we would have used a Chi2 test for homogeneity to determine the strength of evidence that heterogeneity was genuine.

\section{Assessment of reporting biases}

We would have drawn funnel plots (estimated differences in treatment effects against their standard error) if we had found sufficient studies. Asymmetry can be due to publication bias, but can also be due to a relationship between trial size and effect size. In the event of a relationship being found, we would have examined clinical diversity of the studies (Egger 1997).

\section{Data synthesis}

Where the interventions were the same or similar enough, we planned to synthesize results in a meta-analysis if there was no important clinical heterogeneity. If no significant statistical heterogeneity was present, we planned to synthesize the data using a fixed-effect model. Otherwise, we would have used a random-effects model for the meta-analysis.

\section{Adverse events}

Since numbers are small and follow-up is too short in randomized studies for comprehensive adverse events reporting, we planned to discuss adverse events taking into account the non-randomized literature.

\section{Cost-benefit analyses}

Where relevant data were available, we planned to consider the cost-effectiveness of interventions.

\section{Subgroup analysis and investigation of heterogeneity}

If data permitted, we planned to conduct subgroup analyses for:

1. different age groups (younger than 12 years, 12 to 18 years, older than 18 years);

2. different degrees of pre-existing respiratory impairment (mild, severe);

3. different severity of scoliosis (moderate, severe);

4. previous corticosteroid treatments (yes, no). 


\section{Sensitivity analysis}

We planned to undertake sensitivity analyses to assess the impact of study quality. We would have undertaken these including:

1. all studies;

2. only those with low risk of selection bias;

3. only those with low risk of performance bias;

4. only those with low risk of attrition bias;

5. only those with low risk of detection bias.

We would also have performed sensitivity analysis including and excluding participants who might have Becker muscular dystrophy or an intermediate phenotype to see whether this would alter any of the results.

\section{WHAT'S NEW}

\begin{tabular}{lll}
\hline Date & Event & Description \\
\hline 6 February 2015 & $\begin{array}{l}\text { New citation required but conclusions } \\
\text { have not changed }\end{array}$ & Searches updated and results incorporated. \\
\hline 5 January 2015 & New search has been performed & $\begin{array}{l}\text { Review updated with search update to 16 June 2015. Two ex- } \\
\text { cluded studies added. }\end{array}$ \\
\hline
\end{tabular}

\section{H I S T O R Y}

Protocol first published: Issue 3, 2005

Review first published: Issue 1, 2007

\begin{tabular}{lll}
\hline Date & Event & Description \\
\hline 4 January 2013 & $\begin{array}{l}\text { New citation required but conclusions } \\
\text { have not changed }\end{array}$ & $\begin{array}{l}\text { Review updated with search update to July 31 2012 but no new } \\
\text { studies found. Two of the original authors withdrawn. }\end{array}$ \\
\hline 7 November 2012 & New search has been performed & $\begin{array}{l}\text { Two studies added to excluded studies tables. Minor editorial re- } \\
\text { visions. }\end{array}$ \\
\hline 22 August 2010 & New search has been performed & Review updated with search update but no new studies found. \\
\hline 13 May 2009 & Amended & Acknowledgement added. \\
\hline 2 October 2008 & New search has been performed & Updated review. \\
\hline October 2006 & $\begin{array}{l}\text { New citation required and conclusions } \\
\text { have changed }\end{array}$ & Substantive amendment. \\
\hline
\end{tabular}

\section{CONTRIBUTIONS OF AUTHORS}

Daniel KL Cheuk: protocol development, searching for trials, quality assessment of trials, data extraction, data input, data analyses, development of final review, corresponding author.

Virginia Wong: protocol development, searching for trials, quality assessment of trials, data extraction, data analyses, development of final review.

Elizabeth Wraige: protocol development, searching for trials, quality assessment of trials, data extraction, data analyses, development of final review. 
Peter Baxter: protocol development, searching for trials, quality assessment of trials, data extraction, data analyses, development of final review.

Ashley Cole: protocol development, searching for trials, quality assessment of trials, data extraction, data analyses, development of final review.

\section{DECLARATIONS OF INTEREST}

Daniel KL Cheuk: none known.

Virginia Wong: none known.

Elizabeth Wraige: none known.

Peter Baxter: no competing interests.

Ashley Cole:none known.

\section{SOURCES OF SUPPORT}

\section{Internal sources}

- None, Other.

\section{External sources}

- None, Other.

\section{DIFFERENCES BETWEEN PROTOCOL AND REVIEW}

Risk of bias methodology updated in accordance with the Cochrane Handbook for Systematic Reviews of Interventions (Higgins 2011). Change in authorship: Tracy N'Diaye and Varaidzo Mayowe ceased authorship at an earlier update.

In the January 2015 update the electronic searches included the WHO International Clinical Trials Registry Platform.

\section{NOTES}

New evidence on this topic is slow to emerge. The next update is planned in 2019, although an earlier update will be considered if studies eligible for inclusion are performed in the interim.

\section{N DEX TERMS}

\section{Medical Subject Headings (MeSH)}

Muscular Dystrophy, Duchenne [ ${ }^{\star}$ complications]; Scoliosis [complications] [ ${ }^{\star}$ surgery]; Spine [surgery]

\section{MeSH check words}

Humans 